\title{
خصائص هدرسة زرياب في اختبار الأصوات وتعليم غناء الألحان العربية و توظيفها لطلاب الكليات المتضصصة
}

\author{
د. / فاطمة أحمد إبراهيم غريب \\ كلية التربية النوعية - جامعة المنصورة
}

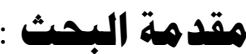

يعد الغناء من أقدم الوسائل التي أستخدمها الإنسان في التعبير عن نفسه ومشثاعره ، غير أنه يصعب تحديد متي بدأ الإنسان في ممارسة القناء .

والفيلسوف الإغريقي أفلاطون يقول :

" من حزن واغتم فليسمع الأصوات الحسنة ، فِإن النفس إذا حزنت خمدت نارها ،

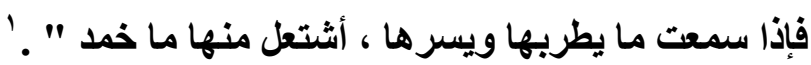

وبتطور العضارة تطور الغناء كسائر العلوم والفنون إلى أن اصبح من ارقي وسائل

التعليم الفني عن المشاعر الإنسانية .

والصوت الجميل هبه من هبات الله سبحاته وتعالي ، فيجب المحافظة عليه بالاهتمام

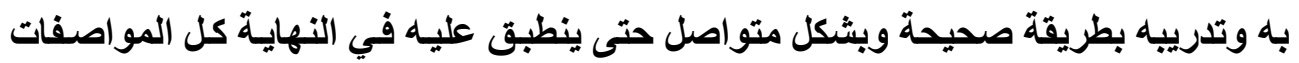

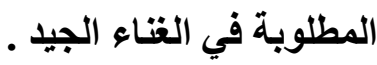

فيقول رسول الله صلي الله عليه وسلم : " حسنوا القرآن بأصواتكم ، فبان الصوت

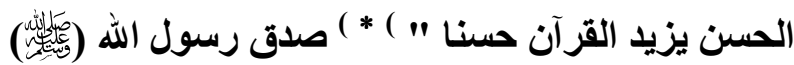
و الرسول (每)

كما يلعب الصوت والقتاء دورا أساسيا في مكونـات وقو الب الموسيقي العربية، فلقد

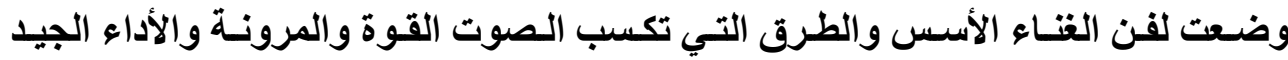


المعبر ، غير أن هذه الأسس كانت تتناقل بفضل التقاليد الشفهية ـ (أي بـالتطبيق العملي

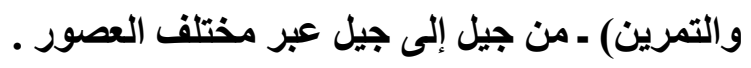

جـاء زريـاب ذلـك الموسـيقي والملحن والـشاعر والمغتـي البـارع ، وابتــــ طريقـة مستحدثة في تعليم الغناء ، تقوم علي أسس فنية ومنهجية تصل بالطالب إلى تحقيق الغايـة كما أن طريقته في اختيار الأصوات كاتت تحمل جوانب فكرية وفلسفية عميقة . ولقد كان لظهور زرياب خلال القترة من ( • 1 هـ : . . r هـ ) كبير الأثر في تكوينه

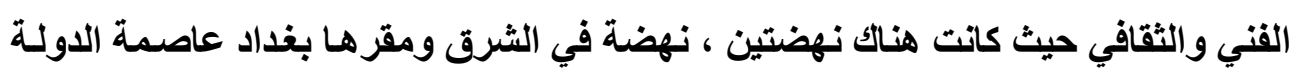
العباسية ، ونهضة في الغرب مقرها قرطبة عاصمة الدولة الأموية بالأنلس .

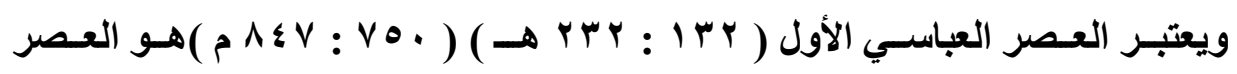
الذهبي للموسيقي حيث وصلت إلى أوج عظمتها فاتسمت الدولـة العباسية بدولـة العلوم

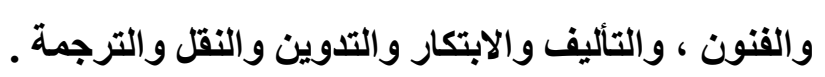

حيث ازدادت عنايـة الخلفـاء بالموسيقي والغتـاء وانتشرت مجـالس الأدب والثقافـة ، وأصبحت مجالس الغناء أشبه بمجالس العلم لدراسة هذا الفن وتهذيبه ، ولقد مـارس هذه

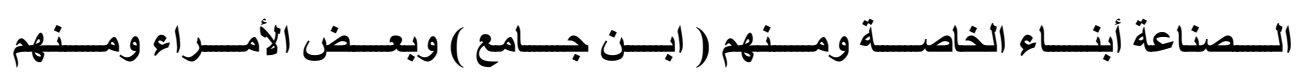

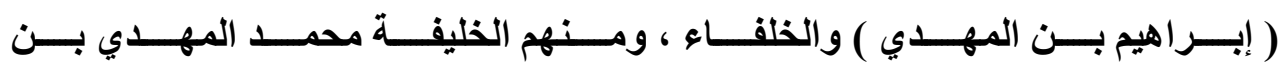

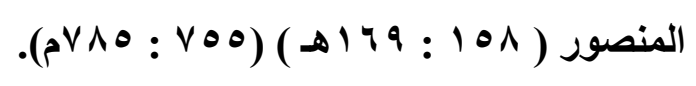
ذكر ابن خلكان : " أنه أحسن الناس صوتا " ' ' ل

كمـا ظهرت الكثير مـن المؤلفـات التاريخيـة في علـم الموسيقي ، تتطرق إلى حيـاة

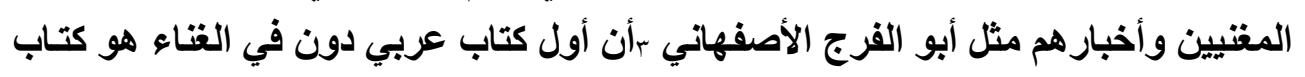

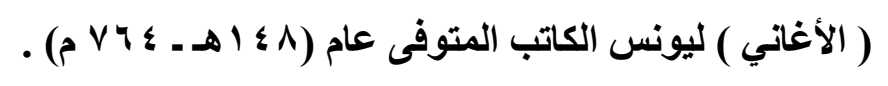

r فاطمة أحمد إبر اهيم غريب : أساليب تدوين الإيقاعات العربية في العصر العباسي وامكانية الاستفادة منها في تدريس

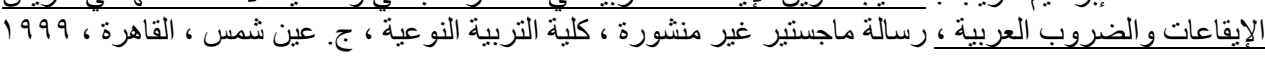

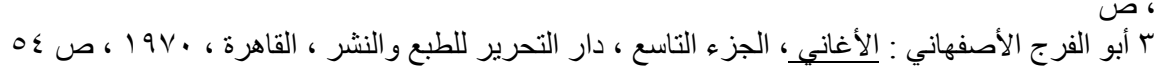


هذا وقد أسسس المسأمون جامعـة(بيت الحكمـة ) ببغداد مقر الخلافة لاراسـة العلـوم والفنون ومنها الموسيقي .

وقد عني العباسيون بتعليم الجواري عناية خاصة ، وقاموا بتدريبهم علي مختلف

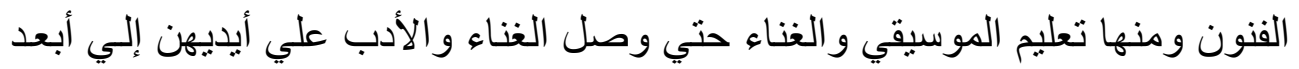

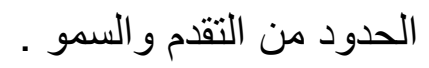
ومن أشهر المغنيات في هذا العصر : دنـانير ، عريب ، عاتكـة بنت شـذا ، ذات الخـال ، متيم الهاشـية ، المغتيـة محبوبـة ،

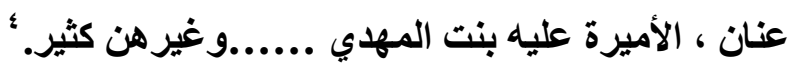
كما حفل هذا العصر بأساطين الغناء والطرب ومنهم : حكم الوادي ، مخـارق ، زلزل ، إبراهيم الموصلـي ، وابنـه اسـق ، وهمـا أستاذا زريـاب

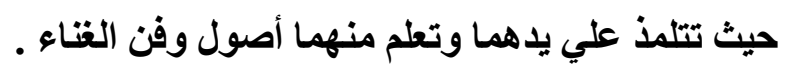
أما الدولة الأندلسية فقد كان لها من المكانة في الغرب مـا للاولة العباسية في الشرق

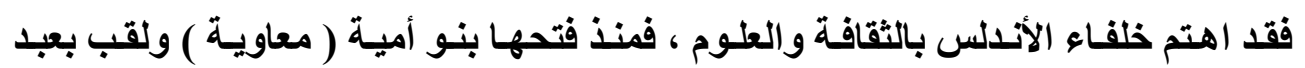

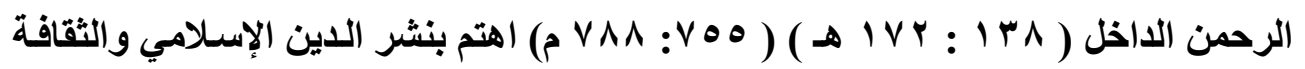

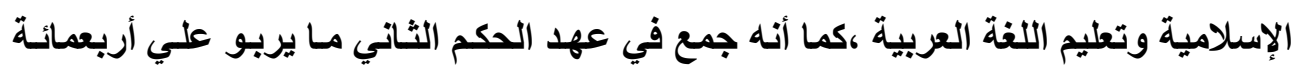
ألف مجلا ، وأصبح هناك نهضة علمية وسياسية ، وكاتت الموسيقي في طليعة هذه العلوم عريم والفنون التي عني بها خلفاء الأندلس . وقد قاموا بـدعوة أسـاتذة الموسيقي والغنـاء مـن مختلف البلاد العربيـة لتعليم فنـون

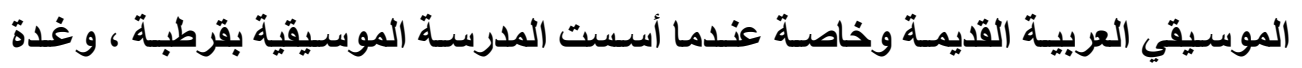
الموسيقي ثقافة عامة يشترك فيها جميع طبقات الثعب .

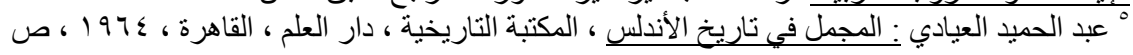




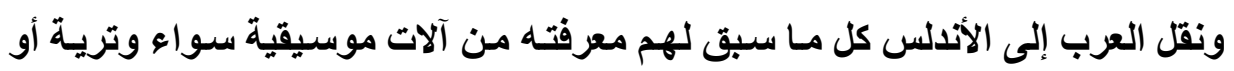

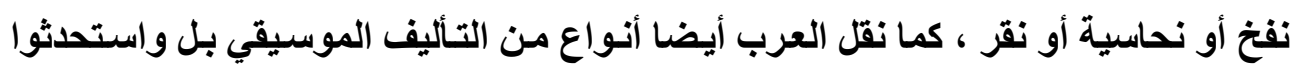

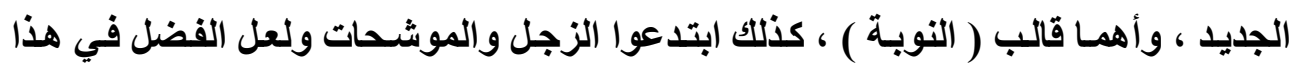

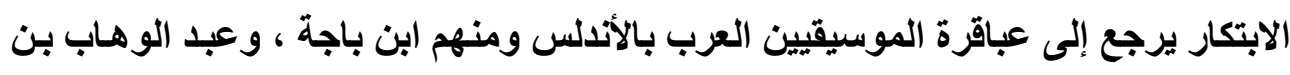
جعفر الحاجب ،وعلي رأسهم زرياب .

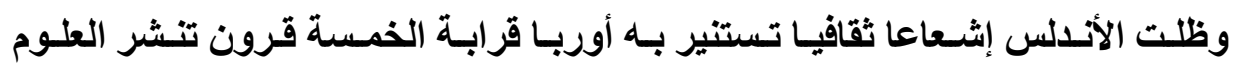

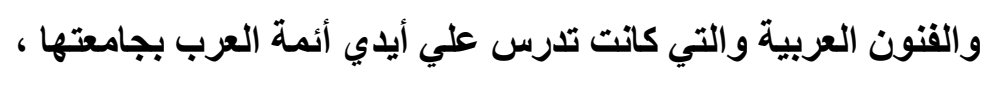

كذلك نقلت أوربا عن العرب الكثير من المؤلفات اليونانية القيمة التي ترجمت إلى العربية

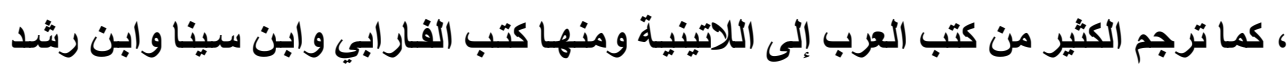

$$
\text { وغير ها الكثير . }
$$

إلى أن سقطت إثبيلية في منتصف القرن الثالث عشر الميلادي ، ممـا أدى إلى نص

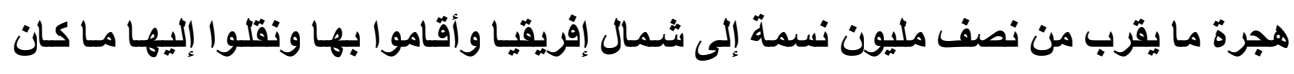

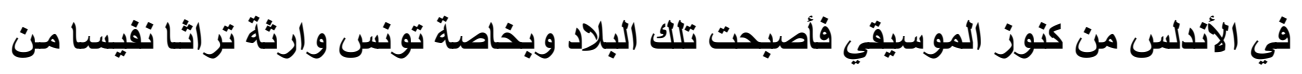

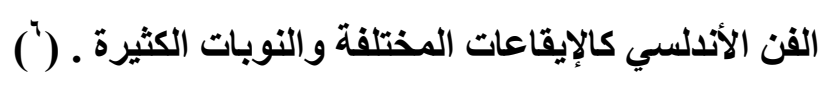

هشكلة البحث :

بالرغم من وجود العديد من مدارس الغتاء العربي القديم التي يمكن الاستفادة منها

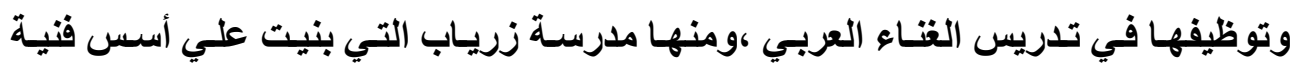

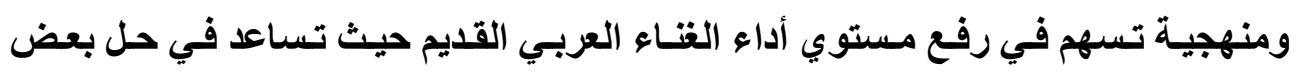
المشكلات الثائعة في أدائه ، إلا أنه لا يتم الاستفادة من هذه آلخاء الخصائص . وتري الباحثة أن اختبار القدرات في الكليات والمعاهد المتخصصة غير مقنن حيث أنسه

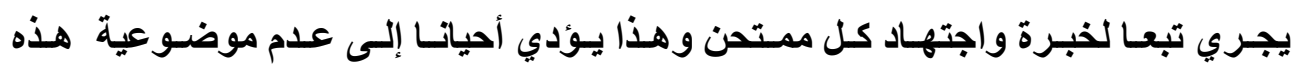
الاختبارات . 
كما لاحظت من خلال تدريسها لمادة الغنـاء العربي القديم أن هنـاك طلاب للديهم عيوب في النطق يصعب حلها عند التدريس بالطريقة التقليدية مما يؤثر سلبا علي أدائهم أثناء الغتاء ، هذا بالإضـافة إلى أن الكثير من الطلاب المتخصصين لا يعرفون فضل زريـاب في وضع بعض أسس وقواعد الغناء السليم . الأهد|ف :

$$
\begin{aligned}
& \text { ا ـ التعرف علي حياة زرياب ومدي اهتمامه بالموسيقي . } \\
& \text { r. التعرف علي أسلوب زرياب في اختيار وتصنيف أصوات المغنيين } \\
& \text { وخصائص مدرسته للغتاء العربي . }
\end{aligned}
$$$$
\text { r. الاستفادة من خصائص ملرسته للغناء العربي من خلال توظيفها في تعليم }
$$$$
\text { الغناء العربي لطلاب الكليات المتخصصة. }
$$

$$
\text { ا ـ معرفة فضل وأثر زرياب في الموسيقي العربية. . }
$$

r. تكمن أهميه البحث في إلقاء الضوء علي أسلوب زرياب في اختيار وتصنيف

الأصوات تبعا لنوعيتها .

r. وبتحقيق تلكك الأهداف قد تسهم في وجود أسلوب مقترح في تدريس الغتـاء العربي

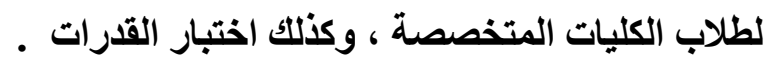

تفترض الباحثة أنه يمكن الاستفادة من طريقة زرياب في اختبار الأصوات ، وكذلك من خصائص مدرسته في تعليم الغناء العربي . أنه يمكن توظيف خصائص مدرسته لتعليم الغناء العربي في الكليات المتخصصة . 
المنهج: يتبع هذا البحث المنهج التاريخ الوصفي التحليلي . ي : عينة عشوائية مـن الموشـات التي تصلح للتدريس لطلاب الكليـات

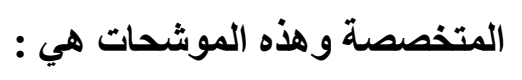

$$
\text { موشح يا شادي الألحان }
$$

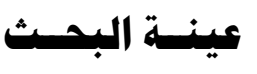

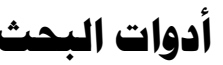

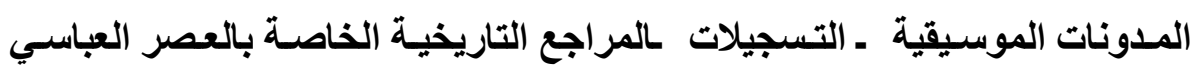

$$
\text { والعصر الأندلسي ،والتي تناولت حياة وأعمال زرياب . }
$$

\section{الإطار النظري}

مولد زرياب ونثأته : هو أبو الحسن علي ابن نـافع ، لقب بزرياب تشبيها لـه بطائر

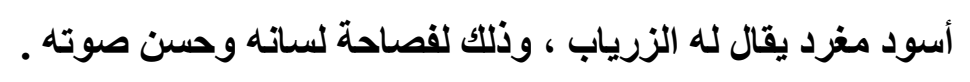

وقد اختلف المؤرخون في تسميته حيث ورد في بعض المراجع أنها سمي بهذا الاسم

نظرا لسواد لونه ،غير أنه لم يثبت أن زرياب كان اسود البشرة .

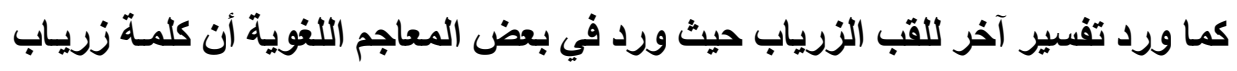

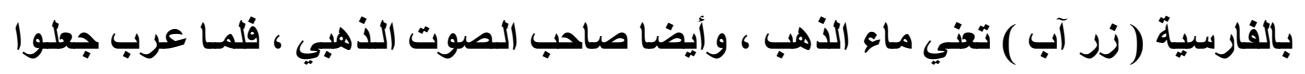

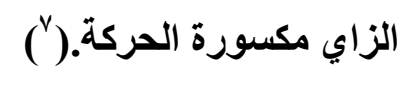

ويرجع أصله إلى بعض عثائر الزنوج التي كانت تسكن بغداد خلال الفترة التي ظهر التهر

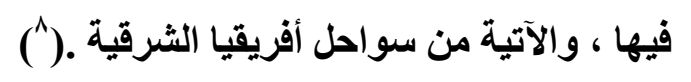

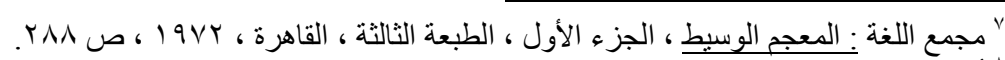

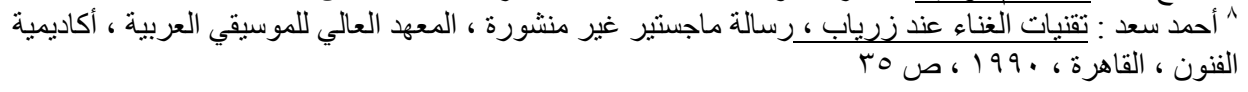




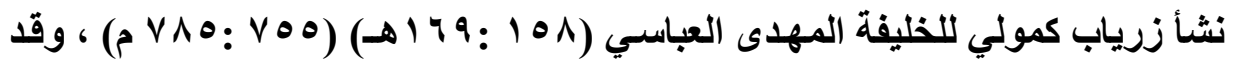
قـام الخليفـة المهـدي بعتقهـه وهو في مقتبـل العمـر، وبعد ذلتك عاصـر الكثير مـن الخلفـاء

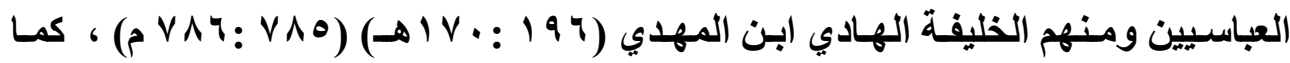

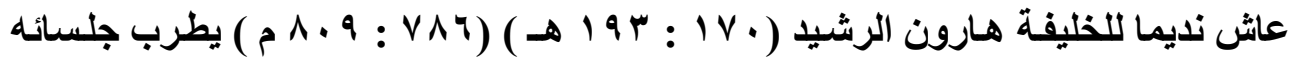
وندمائه؛ وتتلميذ علي اسحق الموصلي ببغداد فحفظ عنه أسـاليب الغتـاء وأسرار التلحين

أما عن مولده فلم ينتبه أحد لتاريخ موللده، حيث كان التاريخ في ذلتك الوقت يسجل حياة و أعمـال الملوك وكبـار القـادة والأمـراء فقط ؛ غير أن بعض المراجـع أوردت أنـه قـا.

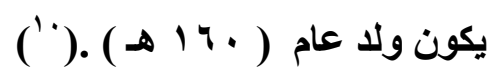

ثقافته : لا شك أن البيئة التي نشأ فيها زرياب كان لها كبير الأثر في شخصيته الفنية بل والاجتماعية ، حيث أنه بحكم تواجده داخل القصور كان عالمـا بشئون الملوك والخلفاء ،

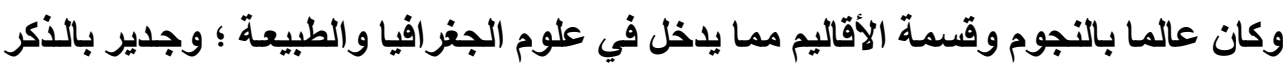
أنه عندما أنتقل إلى الأندلس أخذ عنه أهلها الكثير من الأمور المتعلقة بالأناقة في المأكل

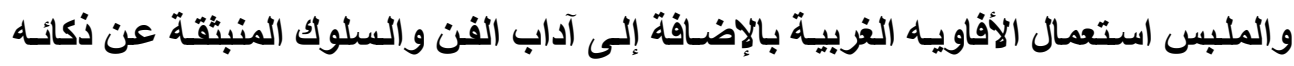
الخاص ما عدا بعض الأثياء التي أخذها عن أستاذة أسحق أو عن غيره ممن تأثر بهم من الإهن

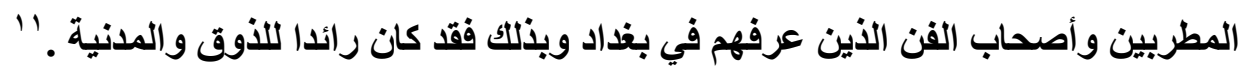
ونظر الوجود أساطين الفن في هذه القصور ومنهم اسحق الموصلي ووالده إبراهيم أستاذاه وملازمته لهم لم تكن ثقاقته قاصرة علي الموسيقي وجودة الغتاء ومهارة العزف فئ فئ فقط بـل تخطي ذلك إلى تحسين صناعه العود إلى درجة تصل إلى الكمسال بل واستحدث

$$
\text { طريقة في اختيار وتصنيف وتعليم الطلاب الغناء ـ (r) ( }
$$

ويعد زرياب أول من فكر في تحقيق مـا نعرفه في يومنـا هذا باسـم ( التبادل الثقافي )

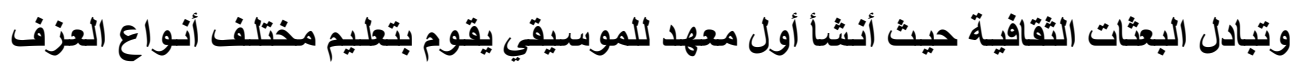

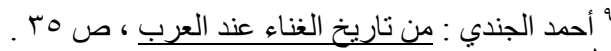

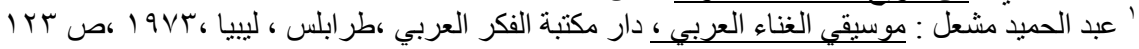

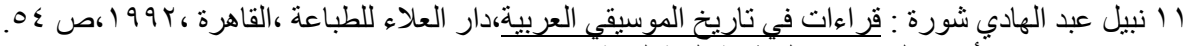

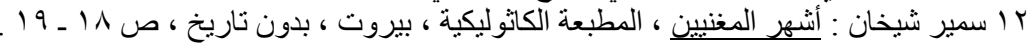


والغتـاء والتلحين والشعر والرقص كـان يفـل إليـه الطلاب من جميع أنحساء العـالم وخاصـة

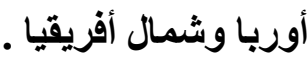

أولاده وجهاريه : بلغ زرياب من المجد درجة رفيعة لم يصل إليها سوي البحتري عند

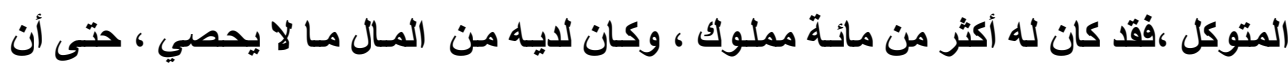
المطرب ( علوية ) قال للخليفة المأمون بعدما غضب عليه الخليفة : " .....مـولاكم زريـاب هله عند موالي الأندلس ويقصد بني أمية ، يركب في مائة غلام ، وأنا عندكم بهذه الحالة ؟وهذا

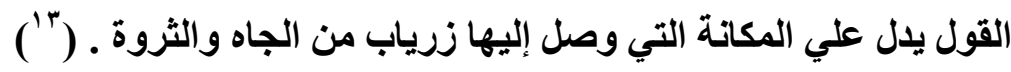
أبنائه : ورث أولاد زرياب فن الغتاء عن أبيهم ، وكـانوا عشرة أولاد ، ثمانيـة ذكور وبنتان ،تعلموا جميعـا الغتـاء ومارسـوا صناعته وأصبحت الأسرة كلها تحترف هذا الفن

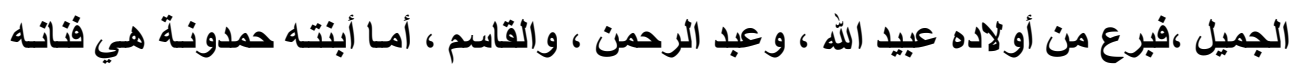

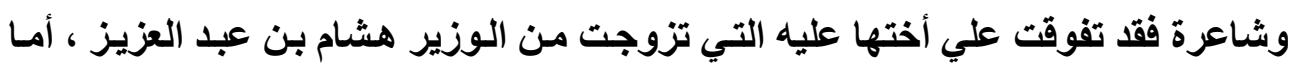

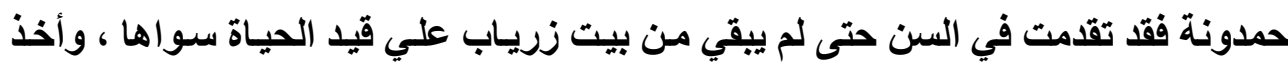
عنها الغناء علي أصوله التي وضعها والدها . جواريه : يرجع الفضل إلى زرياب في المكانة الخاصة التي وصلت إليها الجواري في فن الموسيقي والغنـاء وهذا يرجع إلى تعليمهن وتدريبهن وإلمـامهن بـالعلم والثقافة إلى إلى جانب الجمـال والفن حتي وصـل الغتـاء والأدب علي أيديهن إلى أبعد الحدود مـن التقدم والسمو ، ولعل أبرز جواريه :

• فضل ) وكانـت علـي جاتب كبير مـن الخلق والجمـال والصوت العذب وهـي من جواري هارون الرشيد . • ( علم ) وهي مثل فضل في كل شئ . جارية اسمها ( منفعة ) ثقفها زرياب وأحسن تعليمها . 


$$
\text { ( قلم ) وهي أندلسية الأصل ، وتعلمت أصول الغناء حتى برعت فيه(") ). }
$$

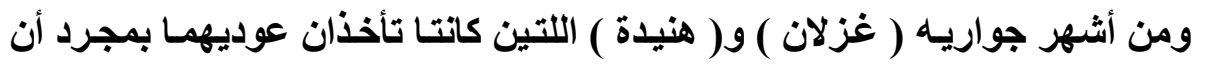

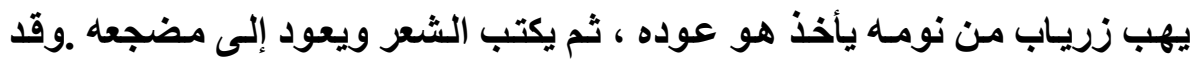

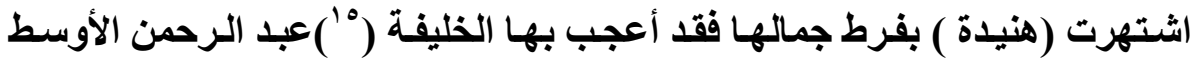
فأهدا ها زرياب إليه وأصبحت من محظياته المقربات. ه ( قمر ) قدمت من بذاد وكانت علي علم بفنون الغناء.

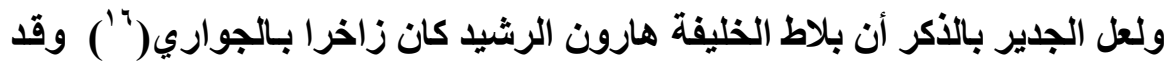

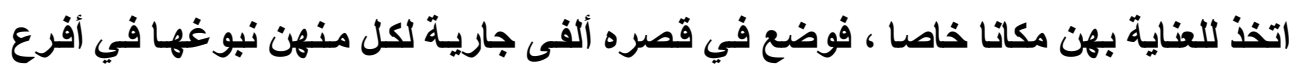

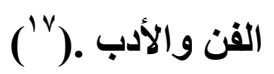

أثر نبوغه في علاقتهه بأستاذه : ورد في كثير من المراجع رواية عن زرياب أن

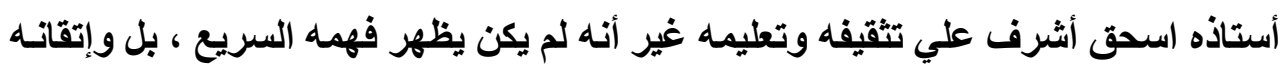

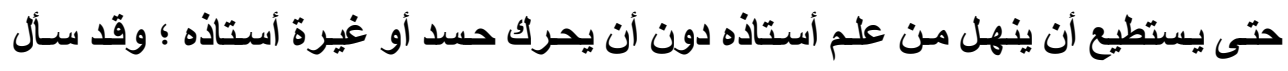

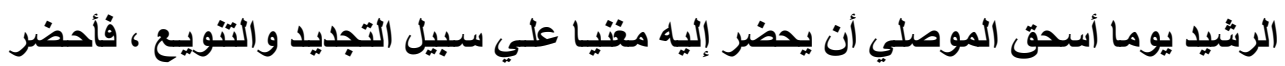

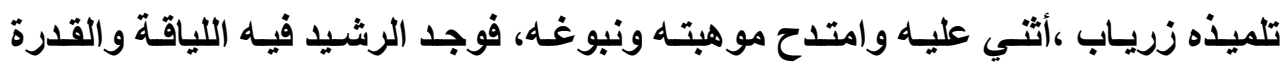
والأدب والصوت الجميل و الضرب الموفق ، وقد امتدحه الرشيد وطار عجبا واستغرابا من

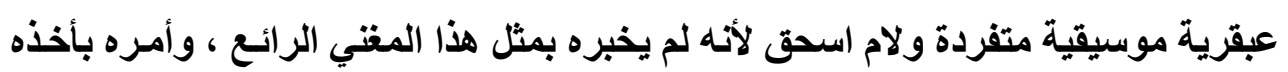

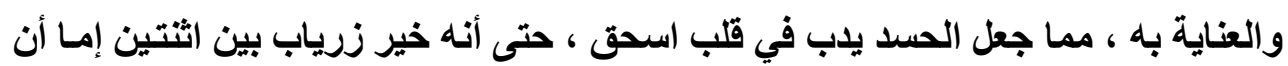

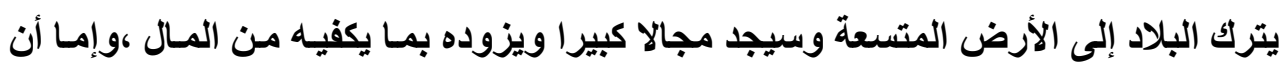
يقيم في بغداد علي كر هل فيستهف من سهامه واغتياله،

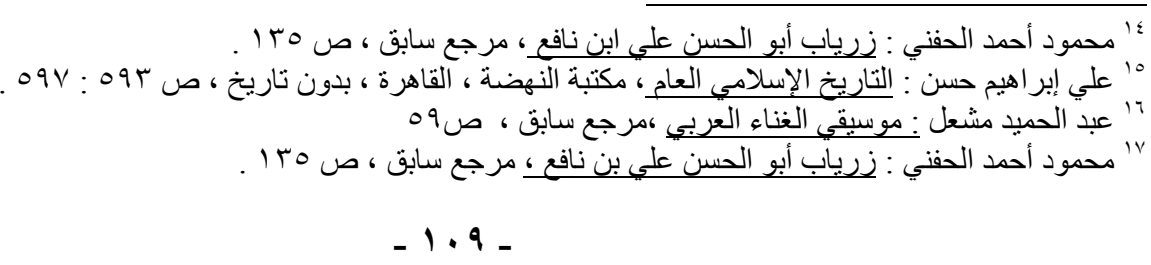


واستجاب زريـاب إلى مـا طلبهـ منـه اسـق وآثر الحيـاة بمنـأى عن المكايــ والحسد ، ورحل إلى ديار الغرب بعدما زوده اسحق بما وعده به ، فلم يكن أمامه سوي أن يسافر إلى

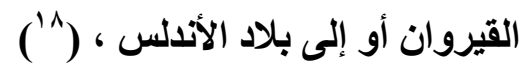
وبالفعل رحل زرياب سرا إلى أن وصل إلى القيروان وعندما وصل إلى هنـاتك استراحت نفسه ، وقد كانت في يـ إبراهيم بن الأغلب ، ولم تنقض السنوات حتى شـاعت النهضة

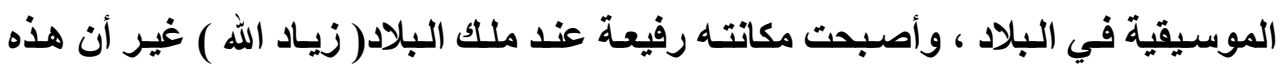

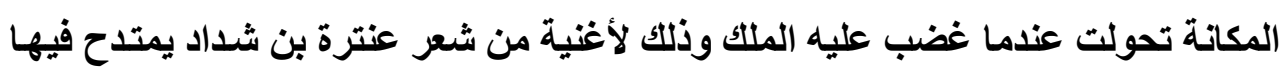
السواد ، مما جعل الملك يأمر بأبعاده عن البلاد . في نفس الوقت حضر ( منصور المغتي ) مبعوثا من خليفة الأندلس (الحكم بن هشام )

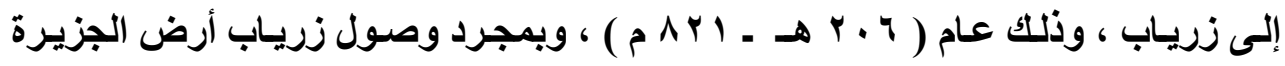

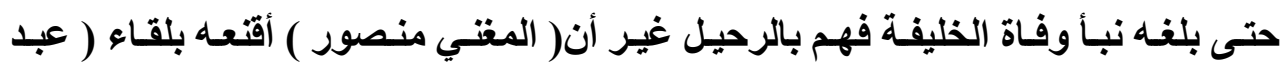

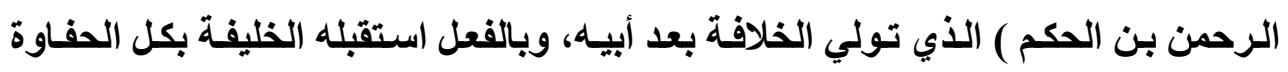
عندما وصل إلى قرطبة وأجزل له العطايا وأمتعه زرياب بذكر أخبار الملوك وسير الخلفاء. ومرة أخري يواجـه زريـاب الحقد والحسد ممن كانت لهم مكانـة قبل وصوله وعلي رأس هؤلاء ( يحيي بن الحكم ) الأي كان يعرف بـ ( الغزال ) وكان شـاعر البلاط المقرب

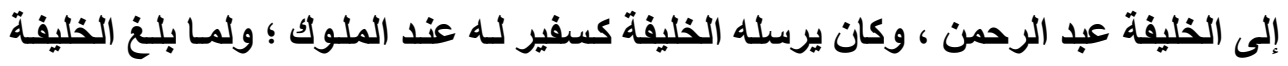
الهجاء الجارح لزرياب غضب علي يحيي وأمر بنفيه مما أضطره إلي السفر وأختار بغداد عله يجد فيها ما فقده في قرطبة ، وبرحيله تراجع حساد زرياب وتوقفوا عن مكائد هم ـ 19

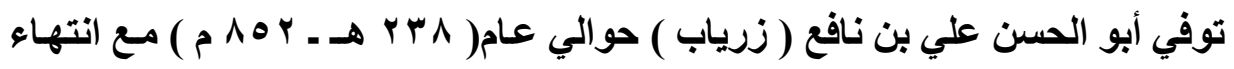

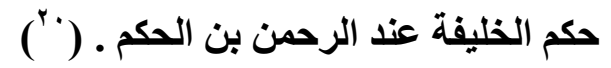




$$
\text { (بتكارات زرياب في الموسيقي : (1) }
$$

• أضاف زرياب مقامـات كثيرة علي الموسيقي الألدلسية لم تكن متداولة من

• وضع أسس الموسيقي الغنائية في الأندلس والتي اعتمدت علي الأسلوب

$$
\text { العربي القايم في عهز اسحق . }
$$

• أضاف الوتر الخامس للعود عمليا بعد أن كانت أوتاره أربعة وجعل مضارب

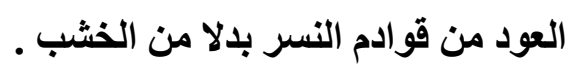

• قام بتأليف مجموعة من الموشحات و النوبات الأندلسية بلغت حو الي عشرة

$$
\text { آلاف لحن. }
$$

• ابتكاره أسلوبا لم يكن متعارف عليه في الغتاء بـأن جعل الوصلة الموسيقية تبدأ بالنشيد أو الأغنية دون الاستعانة بآلات الإيقاع ثم ينتقل المغني إلى لحن

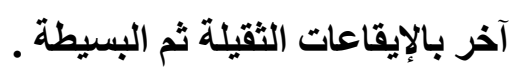

• ادخل أسلوب التناوب الموسيقي علي الفرق الموسيقية ـ ( والتناوب مشتق من كلمة نوبة ) ـ مما جعل آلات الفرقة الموسيقية لا تسير علي خطواحد بل العل

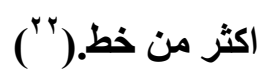

\section{قدراته وهماراته الشفصية :}

• متعه بذاكرة قوية استطاع بها أن يلم بنحو عشرة آلاف أغنية بأحانها.

$$
\text { تضلعه في الموسيقي العربية والغتاء بجاتب العلوم الأخرى . }
$$$$
\text { إتقانه بطلوم الجغرافيا والنجوم و علم القلك ـ }
$$

r محمد محمود سامي حافظ : تاريخ الموسيقي و الغناء العربي ، مكتبة الأنجلوا المصرية ، القاهرة ، 9 ، 19 ، ص

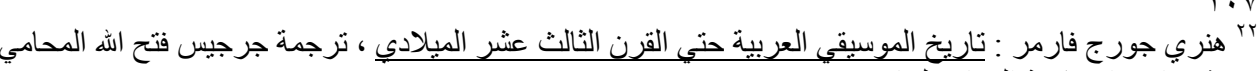

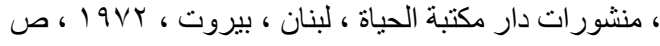


• تأثيره الواضح في بعض الثقافات في شمال إفريقيا خلال القرن الرابع

$$
\text { ( }
$$

\section{المدرسة التي ينتمي إليها :}

ينتمي زرياب إلى مدرسـة الدور الثالث حيث أن الموسيقي العربية مرت في سيرها العلمي علي أربعة أدوار أو مدارس وفي كل مدارسة كاتت تحتل مكانـة جليدة في النهوض هئس

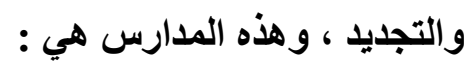

مدرسة الدور الأول : وهي ملرسة الموسيقي العربية الأولي وكانت تعمل علي تطوير

$$
\text { الغناء العربي ثم إدخال الفنون الرومية والإغريقية . }
$$

مدرسه السدور الثـاني : وهي مدرسـة الشراح الإغريق وقد عمل أسـاتذتها غلي نقل الفتـون الإغريقيـة بكل مـا تتميـز بـهـ إلـى الموسـيقي العربيـة مــا أدى إلـى رقـي وسـمو

$$
\text { موسيقانا. }
$$

هدرسة الدور الثالث : وهي المدرسة المنهجية والتي ينتمي إليها زرياب ويعد من أهم أسـاتذتها ، وقـد قامـت بتنظيم موسـيقانـا العربيـة علـي أصـول منهجيـة صـحيحة بأسـاليب تجديدية مما أدي إلى ظهور جمال النغم العربي وتثبيث قواعده وأصوله . مدرسة الدور الرابع : وهي المدرسة الحديثة ـ ( 


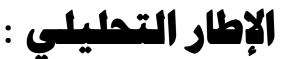

تهاف الاراسة التحليلية إلى الإجابة علي فروض البحث حيث قامت الباحثة

$$
\text { بتوضيح وشرح وتحليل : }
$$

1. مدرسة زرياب في اختيار وتصنيف الأصوات بالإضافة إلى الخصائص التي أسس

عليها هذه المدرسة الغنائية .

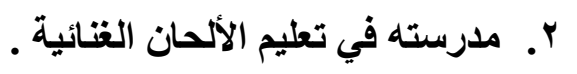

واستعانت الباحثة بعينة عشوائية من الموشحات لتحليلها طبقا لخصائص مدرسـة

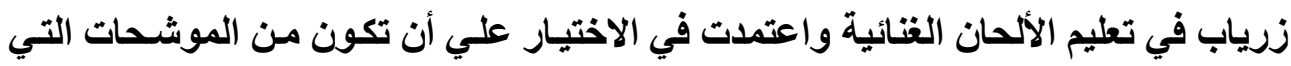
تصلح للتنريس للطلاب المتخصصين في مجال الموسيقي العربية . • أولا : خصائص المنهج الفني الذي اعتمد عليه زرياب في اختبار وتصنيف الأصوات : وقد ذكر دكتور محمود أحمد الحفني هذه الخصائص مجلة كالتالي : " كان إذا تناول الإلقاء علي تلميذ يطلمه ، أمره بالقعود علي الوسـاد المدور المعروف

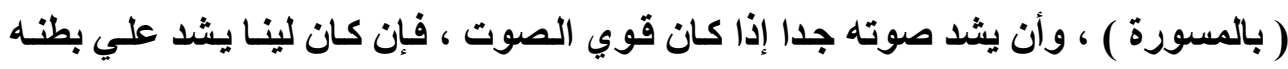

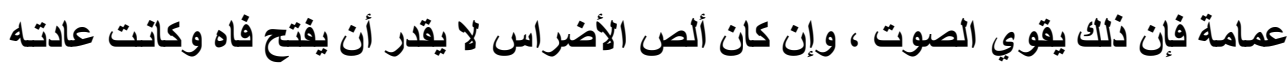

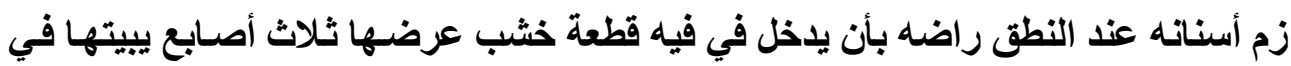

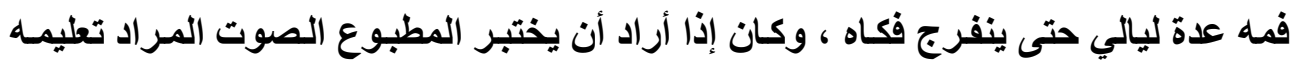

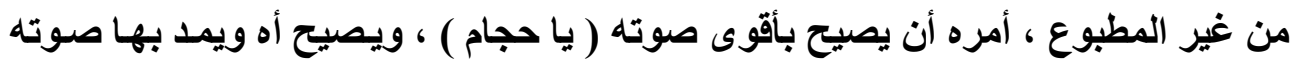

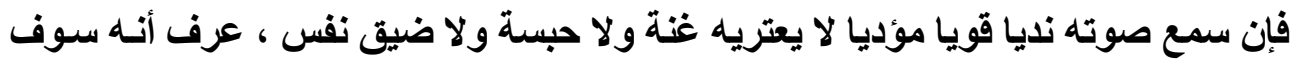

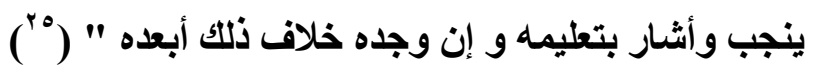


وفيما يلي توضيح أسلوب زرياب في اختبار،واختيار ،وتصنيف الأصوات ، من خلال تفسير المقصود من كل عبارة ذكرها الدكتور الحفني ، ومدي الاستفادة منهاو توظيفها في اختبار القدرات للطلاب المتخصصين: حيث ذكر : " القعود على الوساد المدور المعروف ( بالمسورة ) " والمقصود بهذه العبارة أن زرياب يأمر التلميذ بالجلوس علي مكان مرتفع حتي

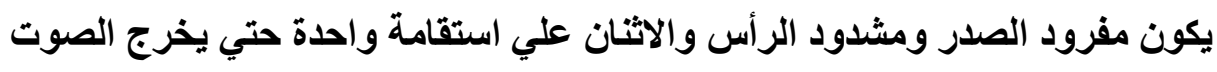
قويا ممدودا بدون عائق .

\section{ويمكن تطبيق ذلك علي اختبار القدرات كالتالي :}

بأن يطلب من الطالب عند اختبـار القدرات أو الغنـاء أن يقف معتدل القامـة بحيث

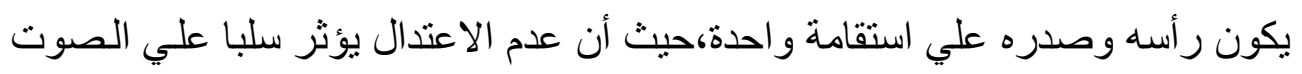
نقصا وفسادا ، وقد ذكر محمد كامل الخلعي أنـه : " علـي المغني أن يحسن نـصبته

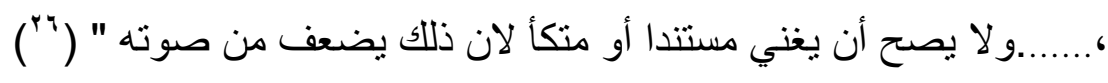
كما ذكر دكتور الحفنى : " وأن يثد صوته جدا إذا كان قوي الصوت " والمقصود بهذه العبـارة أن زريـاب كـان يطلب مـن التلميذ أن يجهر بصوته ويغتي

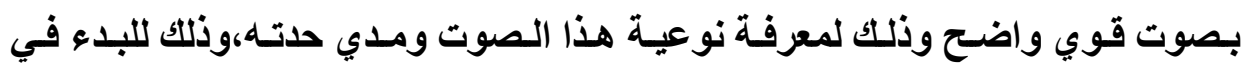
تدريبه.

$$
\text { ويمكن تطبيق ذلك علي اختبار القدرات كالتالي : }
$$

بـأن يطلب مـن الطالب عند اختبـار القدرات أن يأخذ نفس عميق ثم يجهر بصوته ،ويخرج كل ما عنده ، للتعرف علي درجة حدة وغلظ هذا الصوت .

و ذكر دكتور الحفنى أيضا :" إن كان صوته لينا يشد على بطنه عمامة، فِإن ذلك يقوي الصوب إ"

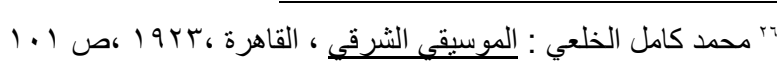


والمقصود بهذه العبارة أنه في حالة كون الصوت ضعيفا يلف حول وسط المغني

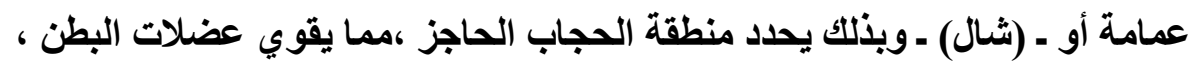

$$
\text { حتى يصدر صوت قوي ممدود . }
$$

\section{وبيمكن تطبيق ذلك كالتالي :}

تري الباحثة أن هذه النقطة يمكن الاستفادة منها في علاج عيب ( ضعف الصوت) ، وعدم القدرة علي تنظيم النفس ، بأن يتدرب الطالب علي أخذ نفس عميق ويقوم

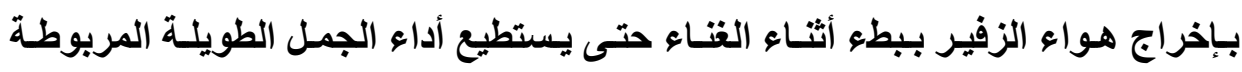
بثكل سليم وبالرنين المطلوب ، وعليه أن لا ينفق كل الهواء الموجود بـالرئتين أثناء

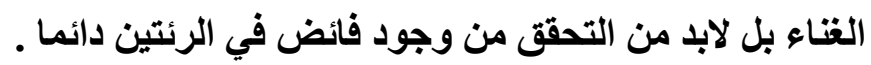
مانمونة

للتأكد من صحة أخذ النفس العميق يجب وضـع يـا الطالب علي بطنه فباذا ارتفعت يكون النفس صحيح ، حيث أنها عند أخذ نفس عميق يصل الهواء إلى أسفل الرئتين

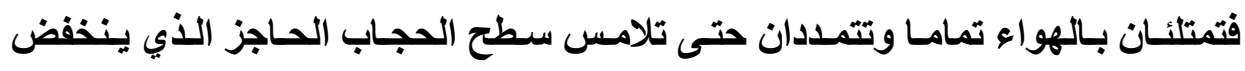
بدوره ليلامس جدار المعدة ويضغطها مما يؤدي إلى ظهور بروز جدار البطن ، أمسا إذا أرتفع القفص الصدري فيكون النفس خاطئ لأنه ملئ الرئتين فقط وبالتالي عند الغناء سيخرج الهواء كله دفعة واحدة أثناء الزفير . كما ذكر دكتور الحفنى : " وإن كان ألص الأضر اس لا يقدر أن يفتح فاه وكاتت عادته زم أسنانه عند النطق راضه بأن بإخل في فيه قطعة خشب عرضـها ثلاث أصسابع يبيتها

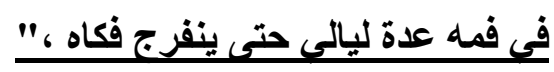

والمقصود بهذه العبـارة إن كانت أضراس الطالب متقاربـة ولا يستطيع أن يفتح

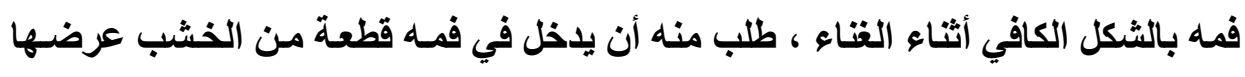
ثُلاث أصابع ويبيتها في فمه عدة ليالي حتى يألف الفم الوضع ومن ثم يبقي فرق طبيعي

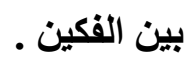




\section{ويمكن تطبيق ذلك كالتالي :}

تري الباحثة أن هذه الطريقة جيدة جدا و يمكن الاستفادة منهـا في معالجة عيوب

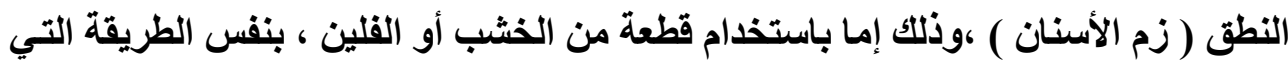

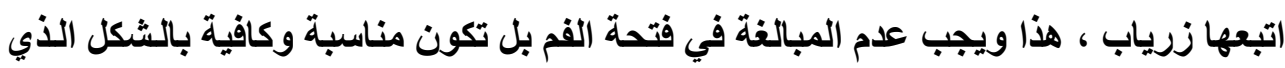
يحافظ علي الهواء داخل التجويف الفمي وكذلك يسمح بخروج الصوت بشكل جيد أثناء

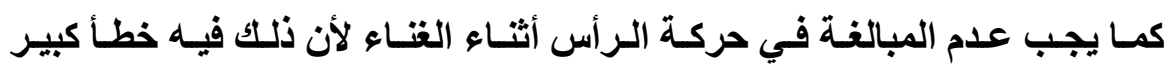

$$
\text { وخاصة عند غناء النغمات الحادة . }
$$

كما تري الباحثة أنه بالرغم من أهمية عدم زم الأسنـان أثناء الغتـاء ، إلا أن هنـاك من

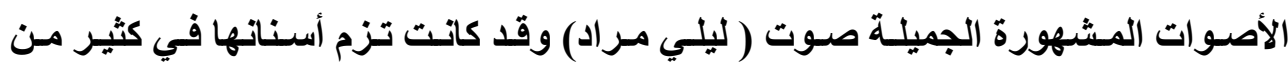
الأحيان .

كما ذكر دكتور الحفنى : " وكان إذا أراد أن يختبر المطبوع الصوت المراد تعليمه من

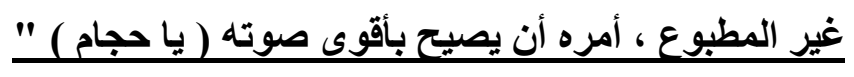
والمقصود بهذه العبـارة أنـه إذا أراد اختبار الصوت القوي الصالح للغتـاء، مـن الصوت الذي لا يصلح ، اختبر مخارج الحروف لايـه ، وطلب من التلميذ الجهر بكلمـة

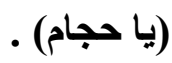

وتري الباحثة أنه بالإمعان في هذه الكلمة و تحليل حروفها وأماكن خروجها ينتج 


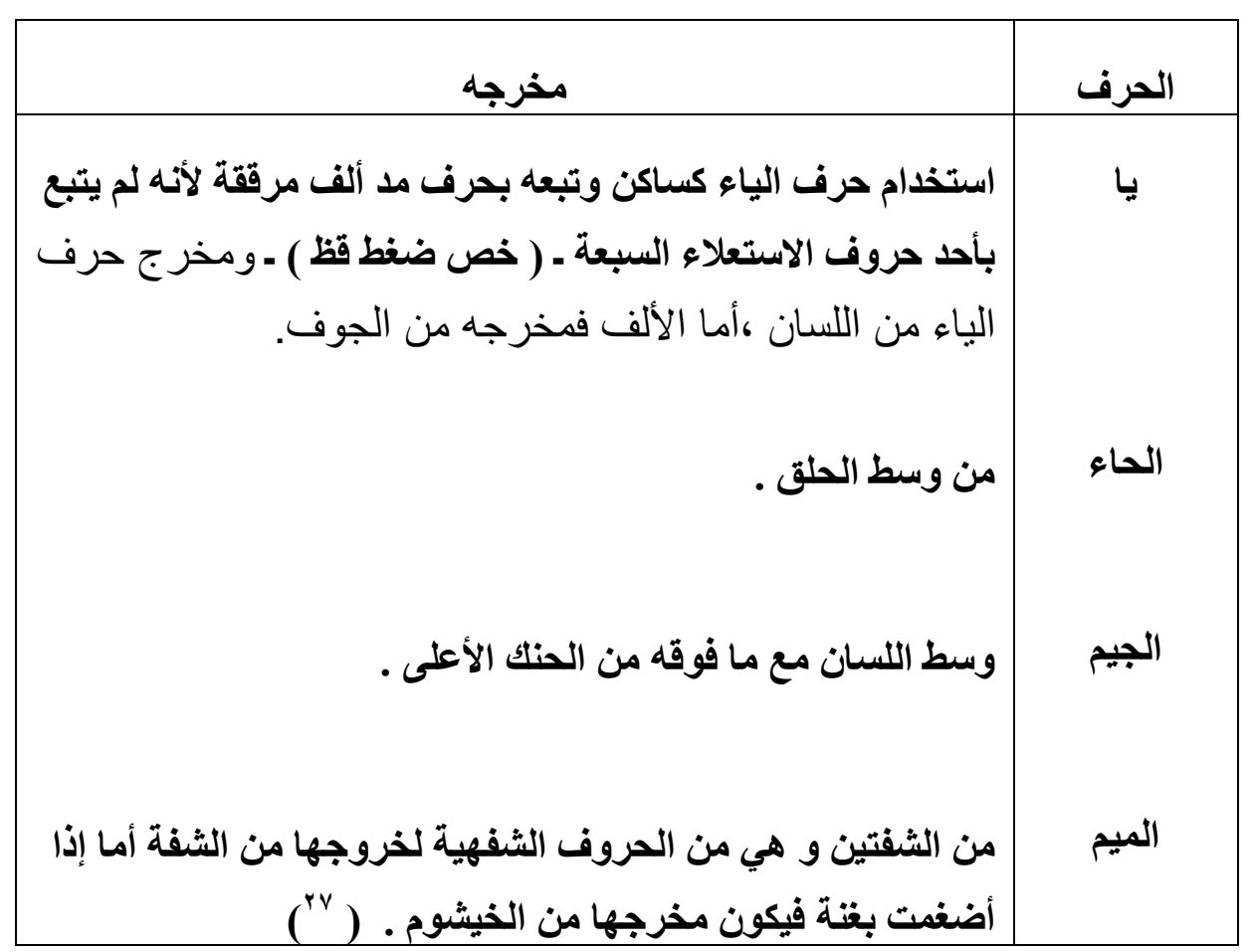

$$
\text { جدول رقم ( ) - (1) - ( ) }
$$

أي تثتمل علي معظم مخارج الحروف وهي : الثفتان ، اللسان ، الحلق ، الجوف ،

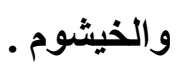

$$
\begin{aligned}
& \text { أما عن التقطيع العروضي لهذا اللفظ فتأتي كالتالي : } \\
& d d \\
& \text { لان } \\
& \text { جام ح }
\end{aligned}
$$

أي تشنتمل علـي جميع مقـاطع العروض الشعري ( المقطع الطويـل [يــ] ، المقطع القصير [ح ] ، ، المقطع الأطول [جام] ) 


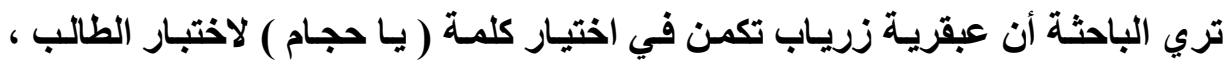

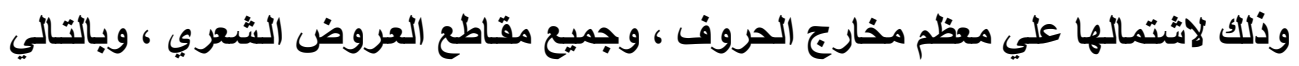
العروض الموسيقي ( . - ، U) .

\section{ويمكن تطبيق ذلك علي اختبار القدرات كالتالي :}

إدراج كلمة ( يا حجام ) ضمن اختبار القدرات في الكليات والمعاهد المتخصصة بأن

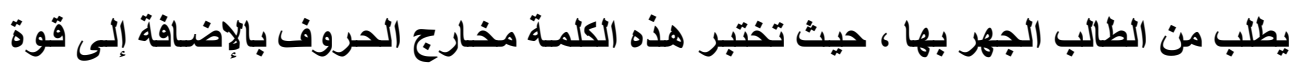
الصوت ، والقدرة علي أداء مختلف المقاطع العروضية بسهولة ويسر . كما ذكر دكتور الحفنى : " ويصيح أه ويمد بها صوته " :

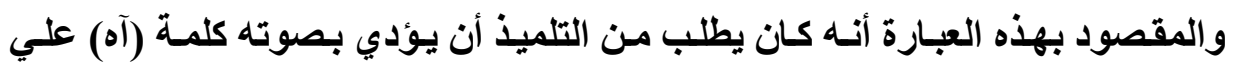

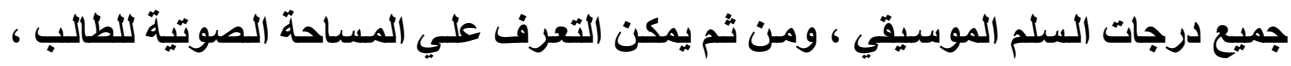
بالإضافة إلى معرفة قوة حنجرته ومقدرته الغنائية ،ويلاحظ أن هذا الحرف يعطي العرفي التساعا

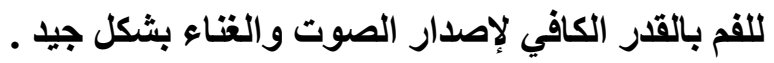

\section{ويمكن تطبيق ذلك علي اختبار القدرات كالتالي :}

بأن يطلب من الطالب عند اختبار القدرات أن يغتي - ( مـا يسمعه مستخدما لفظ لا ) -

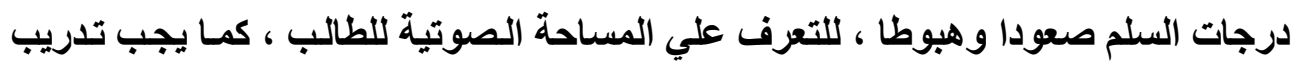

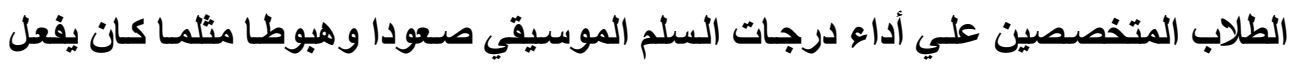
زرياب ، مع مراعاة توضيح كل درجة صوتية صعودا وهبوطا الطيا ، وميع ملاحظة استخدام التنفس الصحيح ، وبصورة طبيعية للتعود علي إخراج الصوت بطريقة سليمة ،ويمكن أداء بعض التلوين و التظليل علي الأداء. .

كما ذكر دكتور الحفنى : " فإن سمع صوته نديا قويـا مؤديـا لا يعتريـه غنـة ولا حبسة ولا

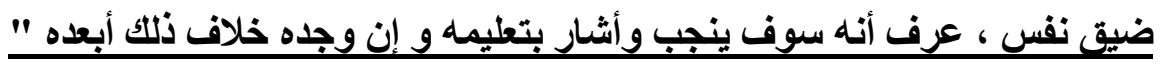


والمقصود بهذه العبارة أن الطالب الأي يجتاز هذه الاختبارات يصلح لتعلم أسس الغتاء الصحيح ، أما إذا لم يجتزه أبعده ، ولم يعلمه .

تمايـق : هكذا ابتكر زريـاب طريقة جديدة و جيدة لاختبـار الصوت من حيث القوة و المرونة، إلى جانب النطق السليم لمخارج الحروف والألفـاظ والمساحة الصوتية

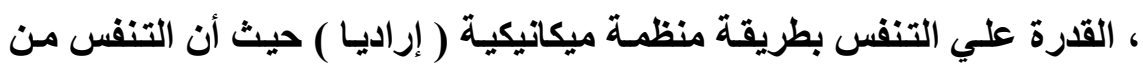

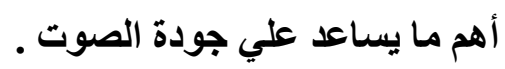

\section{• ثانيا : خمائص هدرسة زرياب في تعليم الألمان الغنائية :}

اعتمد زرياب في تدريسه للألحان الغنائية علي ثلاث مراحل كالتالي :

\section{المرحلة الأولىى : (الإيقاع)}

وفيها يـرس التلميذ نص الشعر المغتي ، ليتعرف علي معانيهه ، وليتعرف علي الميزان الشعري ، ؛ يصاحب القراعة النقر علـي الـدف ليـلـل علـي تفاصيل الميزان الثعري ، ( أي يقرأ الكلمات مع إيقاع اللحن فقط )، ليعرف مواضع السكون والحركة ،

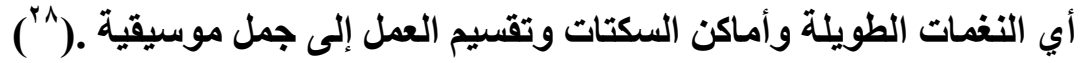
المرحلة الثاتية : ( اللحن البسيط)

يلرس التلميذ اللحن بصورة بسيطة دون أي زخارف أو حليات ويكرر حتي يتقـهـ

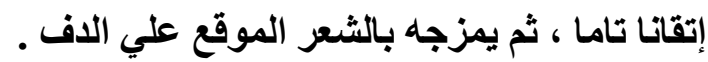
المرحلة الثالثة : ( الزخارف اللحنية)

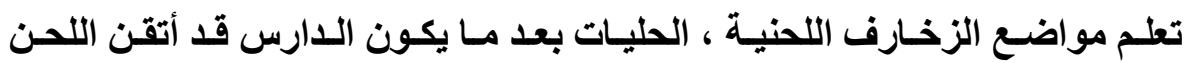
وأصبح متمكنا من أدائه .

التطبيق علي خصائص مدرسة زرياب في تعليم غناء الألحان العربية : موشح يا شادي الألحان 


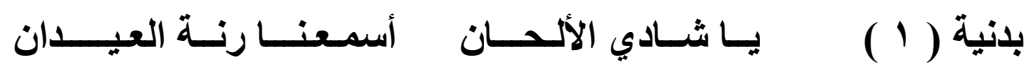

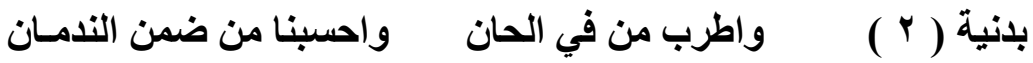

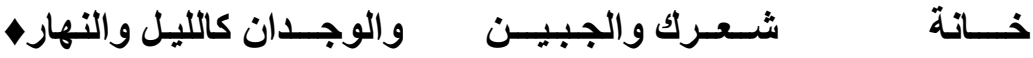

تحليل موشح ( يا شادي الألحان )

الصيغة : ت تأليف غنائي

نوع القالب : الموشتح

اسم الملحن : الثيخ سيد درويش

اسم المقام : مقام الراست

الضرب : المصمودي الكبير

$\varepsilon$

هيكل القالب : يتكون من بانية ( 1 ، ؟ ) ، خانة .

إجمالي عدد الموازير : צr مازورة ، من م ا : م · ب بلنية ( 1 ) ،

من ما Y : م צ Y الخانة .

تحليل المسار اللحني للموشح :

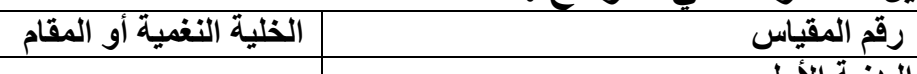

جنس راست النوا هبوطا.

$-1 Y \cdot-$ 


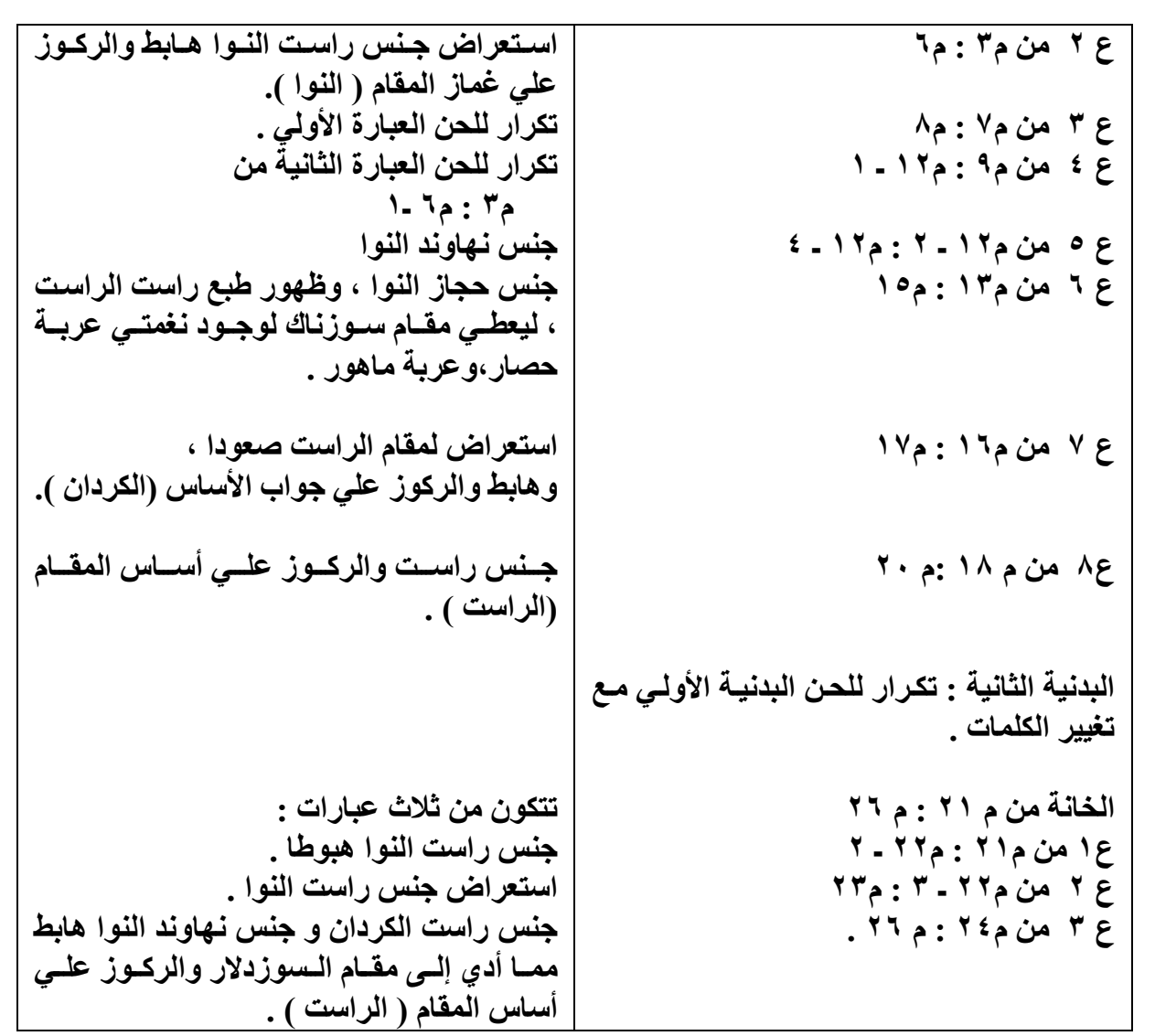

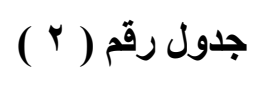

التطبيق علي خصائص مدرسة زرياب :

ا. ــر اعة الأبيـات الشعرية مـع مراعـاة صـوتيات اللغـة العربيـة وقواعــ الإعـراب ؛ يصاحب القراعة النقر علي الدف وذلك لمعرفة التقطيع العروضي للأبيات ،ومنـه

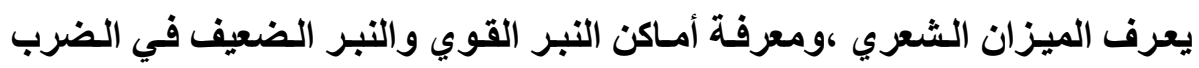

$$
\begin{aligned}
& \text { الواحد أو ما يعرف في وقتنا هذا (دم ، تكل ) . }
\end{aligned}
$$

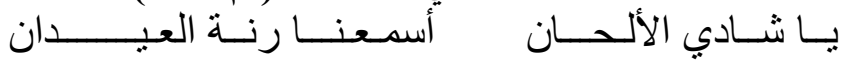

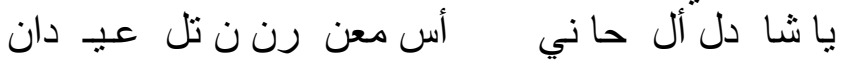

$$
\begin{aligned}
& \text { o o/ o/ o/l o/ o/ o/ ol o/ o/ o/ o/ o/ o/ o/ }
\end{aligned}
$$

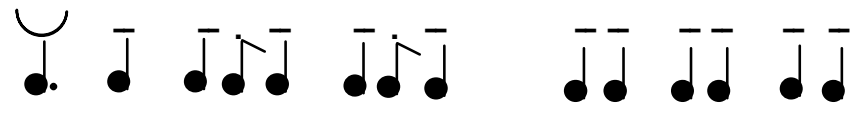




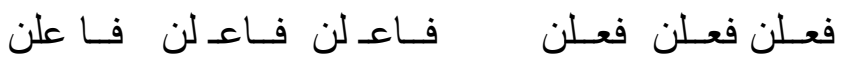

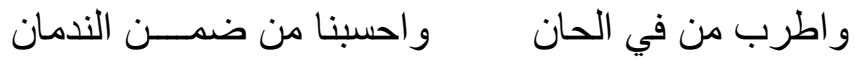

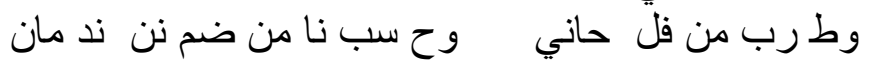

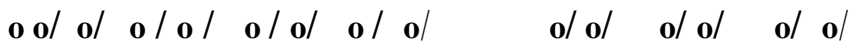

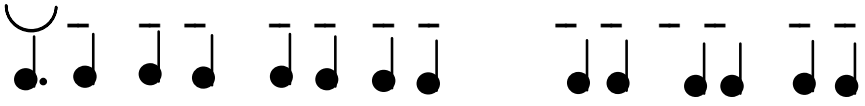
فعـلن فعـلن فعلن فعـلن فعلن فعـن فا علن

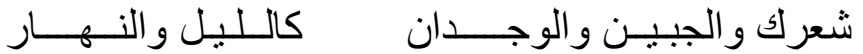
شع رك ول ج بين ول وج دان

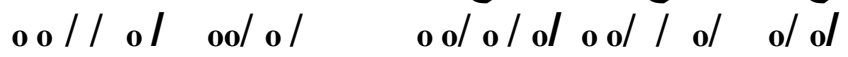
$U_{-} U_{-} U_{-} U_{\text {. }}{ }_{-}$

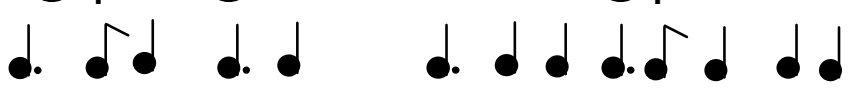

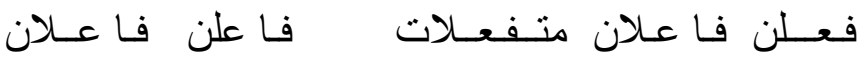

الموشتح من بحر المتدارك وهو من أوزان الثعر العربي المشهورة .

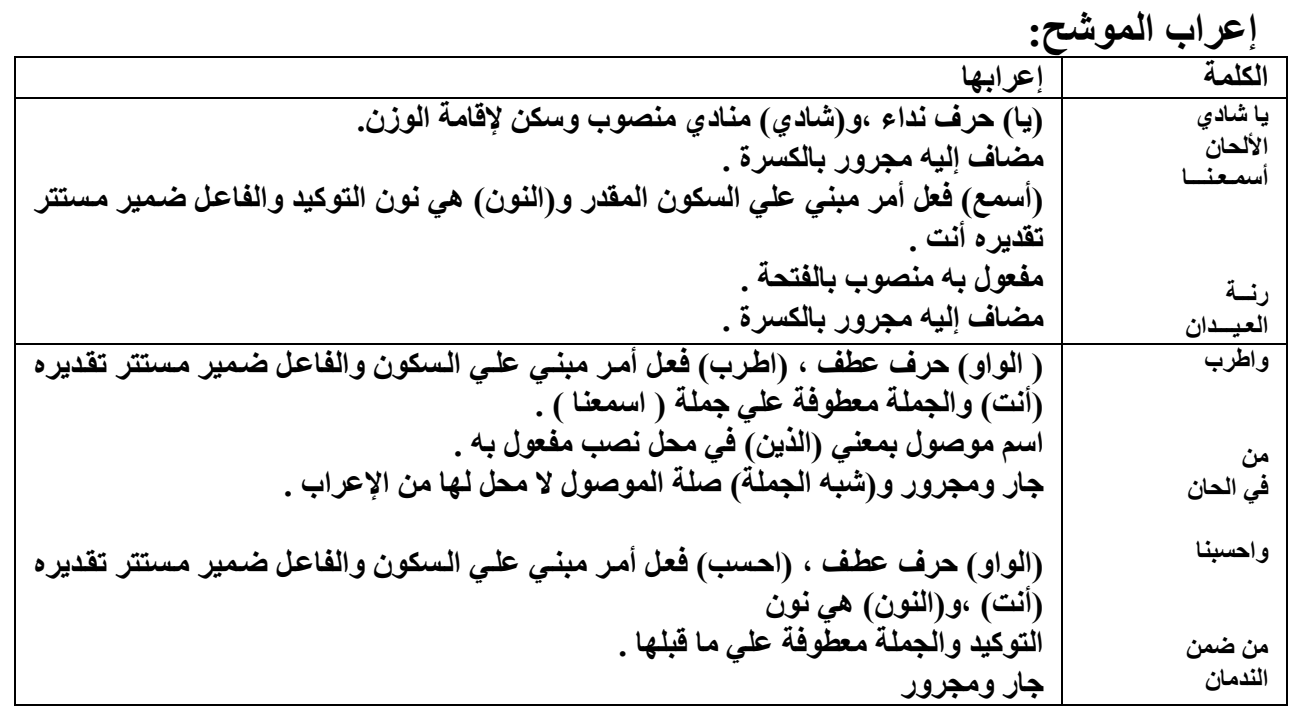




\begin{tabular}{|c|c|}
\hline 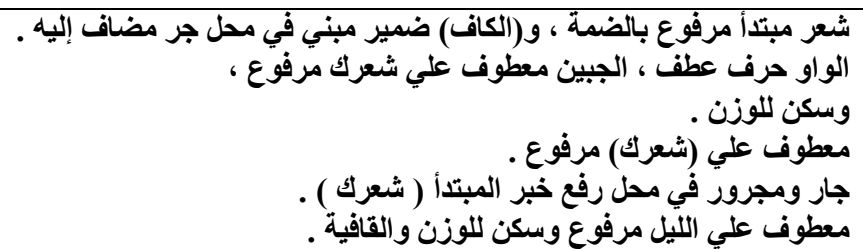 & 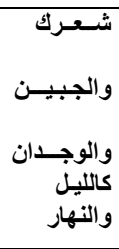 \\
\hline
\end{tabular}

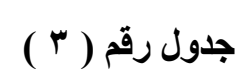

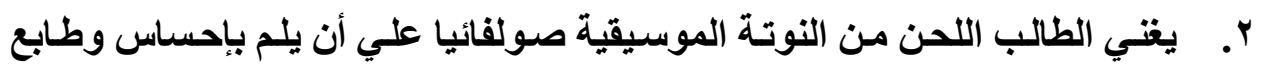

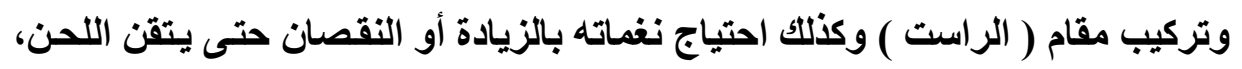

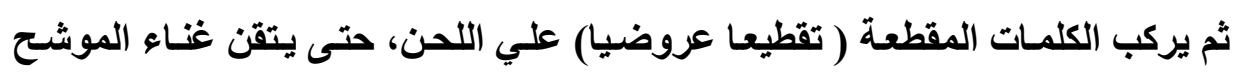

$$
\text { مبسطا دون حليات . }
$$

r. بعد إتقان غناء الموشـح ، يدرس إمكانيـة دخول بعض الزخـارف ، أو الحليات أو مـا

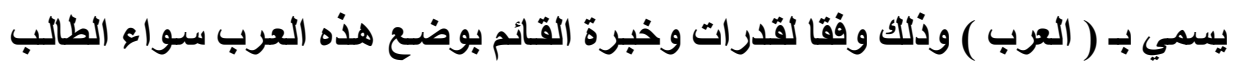
المتخصص أو الأستاذ.

$$
\text { موشح (لو كنت تدري ) }
$$

$$
\text { كالبالوصل يوما ما كنت تبخل }
$$$$
\text { لو كنت تدري ما الحب يفعل }
$$

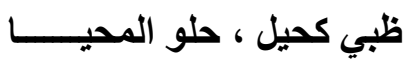$$
\text { يا من هواه أضني فـــــؤادي }
$$

$$
\text { إن كان حبي يقضي بقتلــــي }
$$

تحليل موشح (لو كنت تدري )

الصيغة : تأليف غنائي

$$
\text { نوع القالب : موشح : تابح }
$$

اسم الملدن : مجدي العقيلي : مرسي

$$
\text { اسم المقام : مقام هزام }
$$


اسم مؤلف الكلمات : من الشعر القديم

الضرب : ب سماعي دارج •

$\varepsilon$

هيكل القالب : يتكون من تكرار أربع بدنيات ولازمة موسيقية . إجمالي عدد الموازير : 11 مـازورة ،من م 1 : م 11 ـ ـ بلنية تتكرر أربع مرات، من

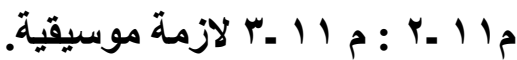
تحليل المسار اللحني للموشتح :

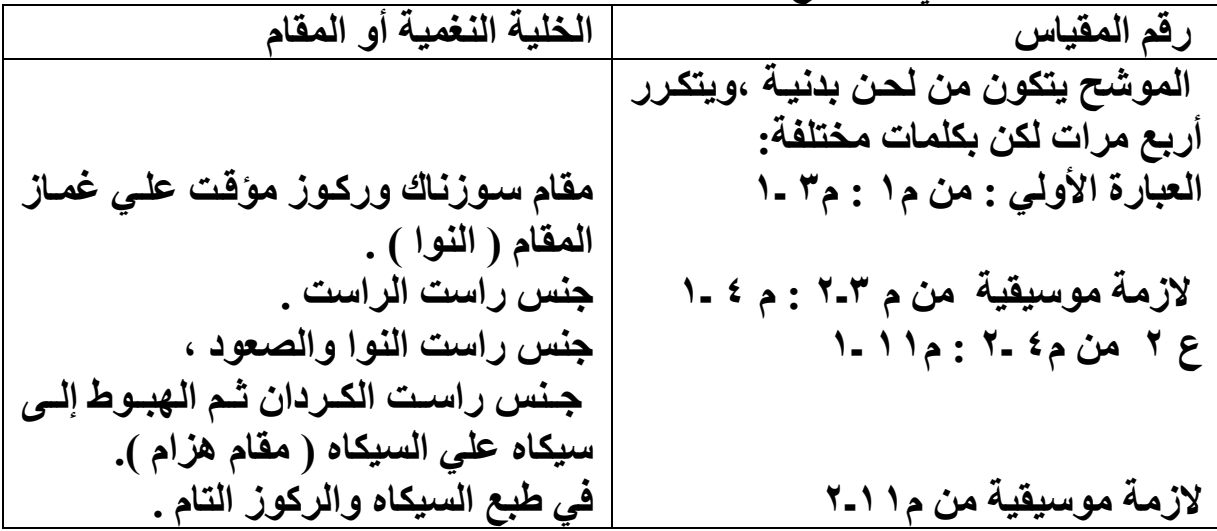

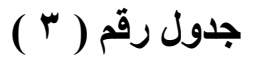

التطبيق علي خصائص مدرسة زرياب :

ا أ الخطوة الأولي : الإيقاع

الموشح من بحر المنسرح التام وهو بحر مشهور بين بحور الثعر العربي . 
بالوصل يوما ما كنت تبخل بل وص ل يالوصل من ما كن ت تب تب خل لو o// o / / o/ ol ol ol / ol ol

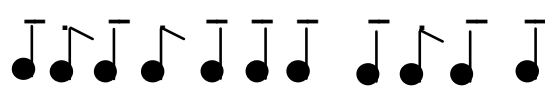
مستفــــلن مفـعولن مــفاعـلن

الغصن منه إن ماس يخجل

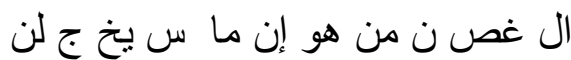
o/ / o/ / ol ol ol ol / o/ o/

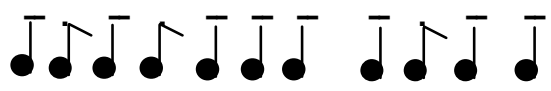

مستفـعـلن مفـولن مـفاعـلن

كالبدر أنت بل أنت أجمل

كل بدر أن تا بل أن أن أجمل ملو أنو o/ / o/ / o/ o/ ol ol / o/ ol

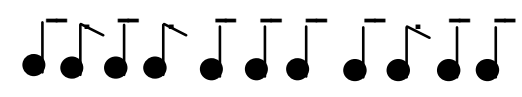

مستفـعـلن مفـعولن مـفاعـلن
لو كنت تدري ما الحب يفعل

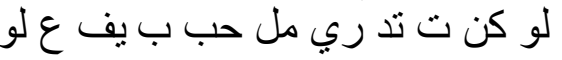
o/ / o / / o/ ol ol ol / o/ ol

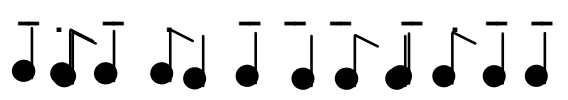
مستفعـلن مفـعولن مسـفاعـلن ظبي كحيل ، حلو المحيا ظب ين ك حي لن حل ول م حي لـ الـا o/ o/ / ol ol ol ol / ol ol

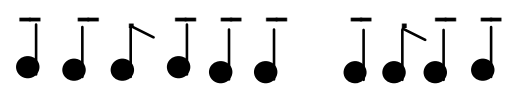

مستفعـلن مفـولن مـفاعل

يا من هواه أضني فؤادي

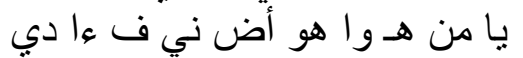
ol o/l ol ol ol ol / o/ ol

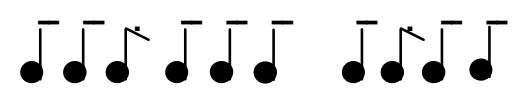

مستفعـلن مفعولن مـفاعل

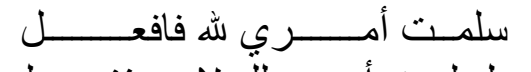

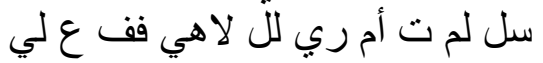
o/ / ol o/ o/ ol ol ol / o/ ol

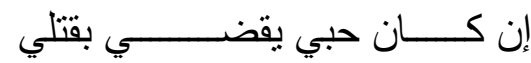
إن كان حب بي يق ضي بـ قت لي لي olo// ol ol ol ol / ol ol c.9.

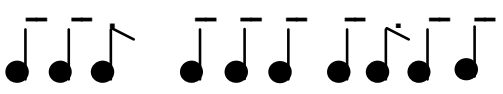

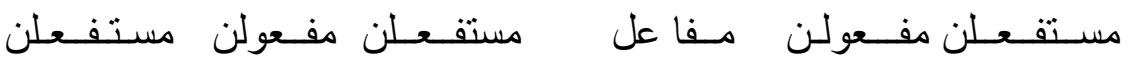


إعراب الموشح:

\begin{tabular}{|c|c|}
\hline إعرابها & الكلمة - الكة \\
\hline (لو) حرف امتــاع لامتــاع ،(كنت) فعل ماضي & لو كنت \\
\hline ناقص و(التاء) أسمها. & \\
\hline فعل مضارع مرفوع بضمه مقدرة ، (والفاعل) & 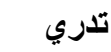 \\
\hline ضـمير مستتر تقديره أنست والجملـة في محل & \\
\hline نصب خبر كان . & \\
\hline أســم موصـول بمعــي (الذـي) مبنــي في محـل & ما \\
\hline نصب مفعول به . & \\
\hline فاعل لفعل مقدم عليه . & 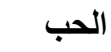 \\
\hline فعل مضارع مرفوع والجملة صلـة الموصول لا & 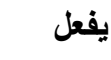 \\
\hline محل لها من الإعراب . & \\
\hline جار ومجرور & 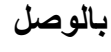 \\
\hline ظرف زمان منصوب & 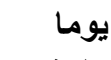 \\
\hline (مـا) نافيـة ،)(كنـت فعل ماضسي نـاقص و التـاء & 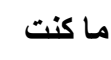 \\
\hline 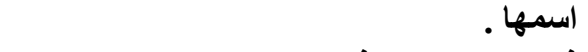 & \\
\hline فعـل مـضارع مرفـوع والفاعلل ضـمير مستتر & 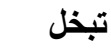 \\
\hline تقديره (أنت)،والجملة في محل نصب خبر كان . & \\
\hline
\end{tabular}




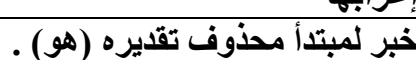

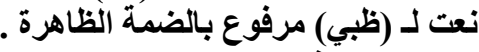

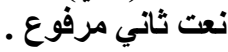

$$
\begin{aligned}
& \text { مضاف إليه مجرور بالكسرة المقدرة لظهور حرف علة . مبرة }
\end{aligned}
$$

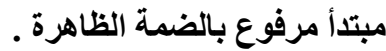

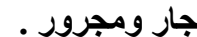

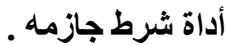

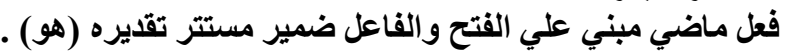

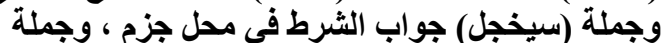

$$
\begin{aligned}
& \text { الثرط ، وجوابه في محل رفع خبر مبتدأ (الغصن) . }
\end{aligned}
$$

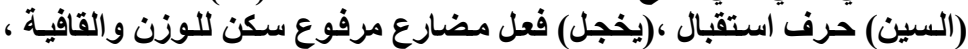

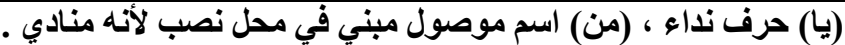$$
\text { (هوي) مبتدأ مرفوع بضمه مقدرة ، (الهاءء) ضمير مبني علي الضم في محل جر }
$$

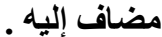$$
\text { فعل ماضي مبني علي القتح ، و الفاعل مستتر تقديره (هو) ، والجملة خبر المبتأ }
$$

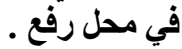$$
\text { مفعول به منصوب بفتحة مقدرة ،و(الياء) ياء المتكلم ضمير مبني علي السكون }
$$

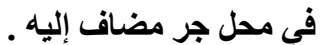

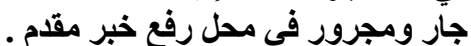$$
\text { ضمير مبني علي الفتح في محل رفير رفع مبتدأ مؤخر . }
$$

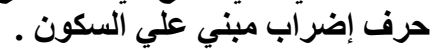

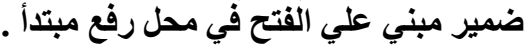$$
\text { خبر المبتاً مرفوع وعلامة رفعله الضمه الظاهرة علي آخره . }
$$

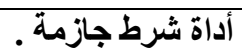

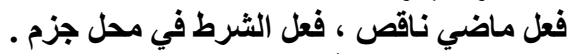$$
\text { (حب) اسم كان مرفوع بضمه فئم مقدرة ، و(الياء) ياء المتكلم ضمير مبني في محل }
$$$$
\text { جر مضاف إليه . }
$$$$
\text { فعل ماضي مرفوع ، و و الفاعل ضمير مستتر تقديره (هو) و الجملة في محل نصب }
$$

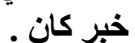

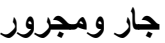$$
\text { (سلم) فعل ماضي مبني علي السكون ، (التاء) تاع الفاعل . }
$$

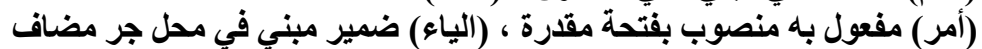


Y. الخطوة الثانية : إتقان اللحن مبسطا مع الإلمام بمقام الهزام ثم r. الخطوة الثالثة : غنـاء اللحن مضافا إليه بعض العرب وذلك وفقا لقدرات وخبرة القائم بوضع هذه العرب سواء الطالب المتخصص أو الأستاذ.

$$
\begin{aligned}
& \text { موشع ( حبي دعاني للوصال ) }
\end{aligned}
$$

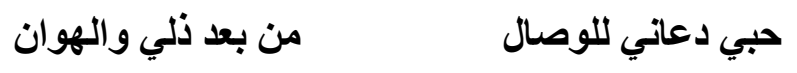

$$
\begin{aligned}
& \text { والوصل يحلو لا كلام يأبي أن يهان } \\
& \text { تحليل موشح ( حبي دعاني للوصال ) } \\
& \text { نوع القالب : تنائي } \\
& \text { نوع التأليف : الموشح } \\
& \text { اسم الملحن :الثيخ سيد درويش } \\
& \text { اسم المقام : مقام قارجغار }
\end{aligned}
$$$$
\text { الضرب : الإ العويص }
$$$$
\varepsilon
$$

هيكل القالب : يتكون من بلنية ( ، ب ). إجمالي عدد الموازير : أربع موازير . 
تحليل المسار اللحني للموشح :

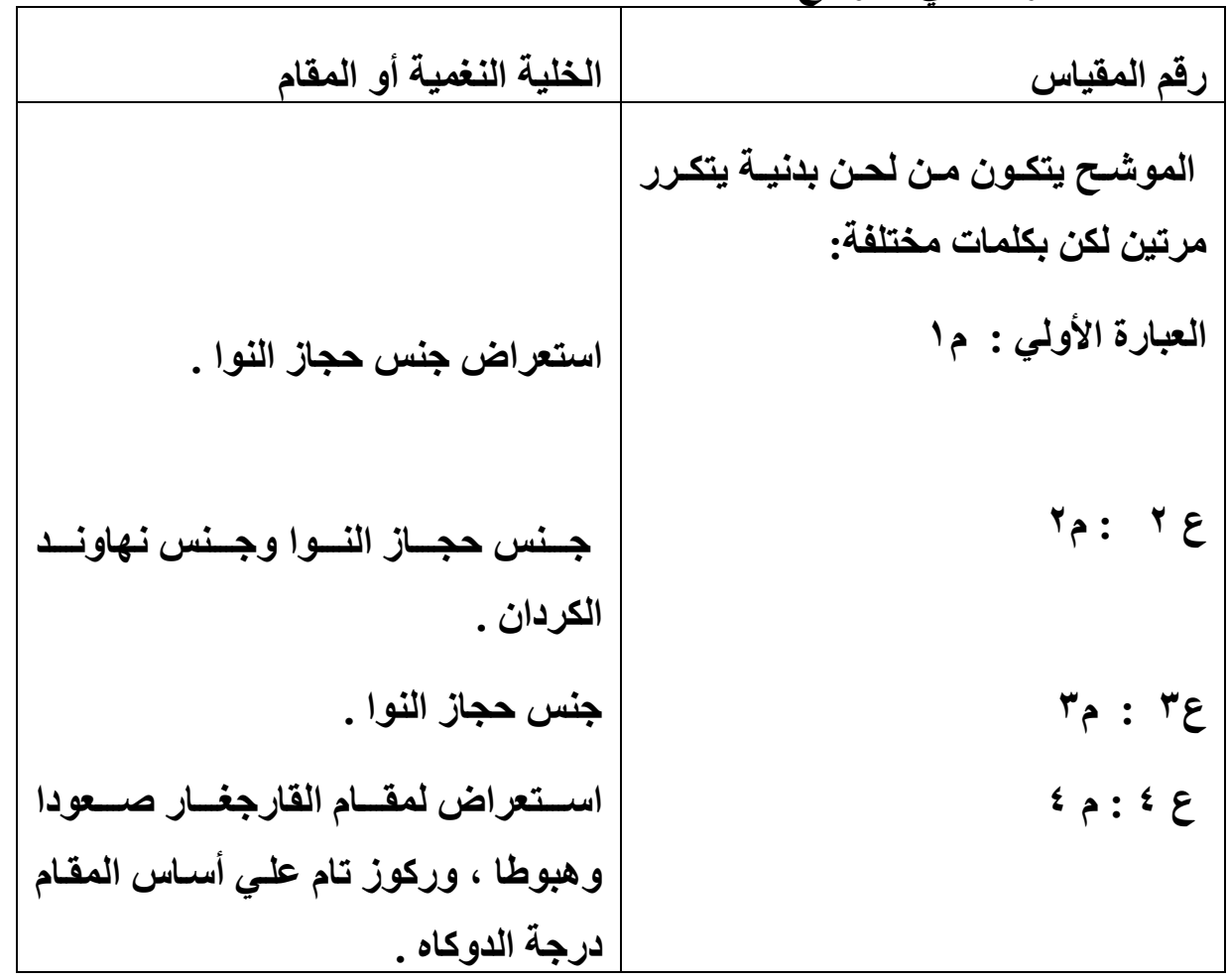

جدول رقم (•) - (•) - (ج)

التطبيق علي خصائص مدرسة زرياب :

ا ـ الخطوة الأولي : الإيقاع

مــن بعـــ ذلـــي و الهـوان

التقطيع العروضيى :

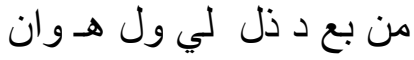
ool / o/ ol o/ / o/ ol

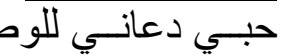

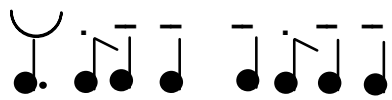

حب بي د عا ني لل وعان للود صال

ool / ol ol ol / ol ol

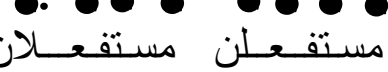

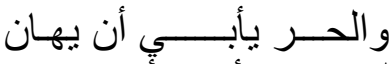

ول حر ر ريأ بي أن بي هان

ool / ol ol o/ / o/ ol

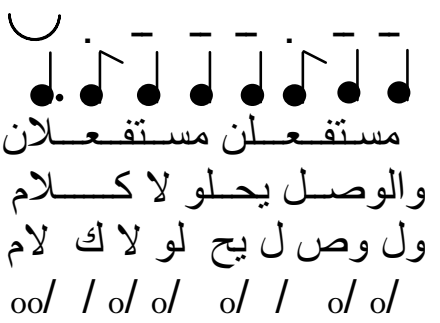

$-1 \times 9-$ 

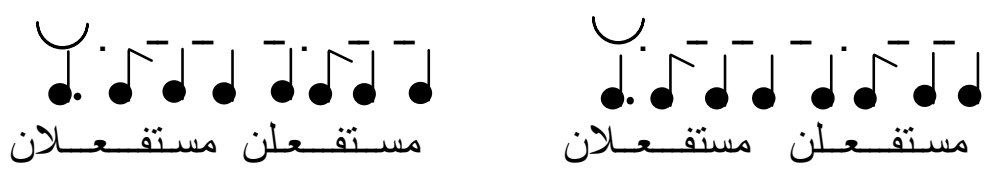

و الموشح علي بحر ( مجزوء الرجز ) وهو من أوزان الثعر العربي المشهورة وتفعيلته

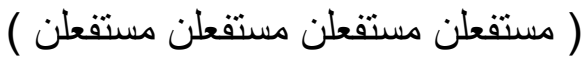

$(\mathrm{o} / / \mathrm{o} / \mathrm{o} / \mathrm{o} / / \mathrm{o} / \mathrm{o} / \mathrm{o} / / \mathrm{o} / \mathrm{o} / \mathrm{o} / / \mathrm{o} / \mathrm{o} /$ )

\begin{tabular}{|c|c|}
\hline \multicolumn{2}{|c|}{ إعراب الموشتح } \\
\hline إعرابها & الكلمة - ت الكة \\
\hline (حب) مبتدأ مرفوع بضمة مقدرة لظهور حرف العلة و(الياء) مضاف إليه . & حبي \\
\hline دعا فعل ماضي مبني علي الفتح ، والفاعل ضمير مستتر تقايره & 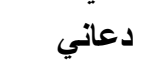 \\
\hline (هو) ، و(النون) للوقاية ،و(الياء) ضمير مبني في محل نصب مفعول به . & \\
\hline جار ومجرور وقد سكن المجرور للوقف . & 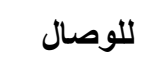 \\
\hline جار ومجرور & 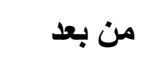 \\
\hline مضاف إليه مجرور و(الياء) ضمير مضاف إليه . & ذلي \\
\hline معطوف علي (ذلي) مجرور . & 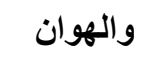 \\
\hline الواو استتنافية ، (الوصل) مبتدأ مرفوع . & 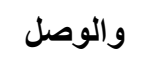 \\
\hline فعل مضارع مرفوع بالضمة المقدرة ، و الفاعل ضـمير مستتر تقديره (هو) & يحلو \\
\hline ،و الجملة في محل رفع خبر المبتدأ . & \\
\hline 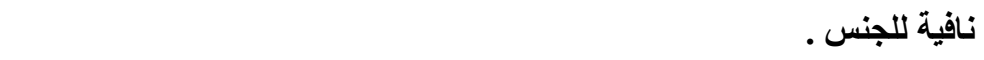 & ل \\
\hline اسم لا مبني علي الفتح وخبر ها محذوف & كلام \\
\hline الواو استئنافية و(الحر) مبتدأ مرفوع & 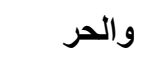 \\
\hline فعل مضارع مرفوع وفاعله ضمير مستتر والجملة في محل رفع خبر المبتدأ . & يأبي \\
\hline حرف مصدري ونصب . & \\
\hline فعـل مـضارع منـصوب بــأن وسـكن للوقف والمسصدر المسؤول مـن أن والفعـل & أن \\
\hline (الإهانة) في محل نصب مفعول به (يأبي) . & يهان \\
\hline
\end{tabular}

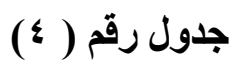


rـ الخطوة الثانيـة : إتقان اللحن مبسطا دون حليات ، يغتي الطالب اللحن من النوتـة الموسيقية صولفائيا علي أن يلم بإحساس وطابع وتركيب مقام (القارجغار)

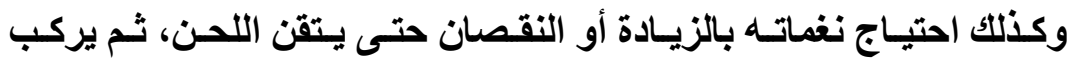
الكلمات المقطعة ( تقطيعا عروضيا) علي اللحن . r ـ الخطوة الثالثة : غناء اللحن مضافا إليه بعض العرب و الزخارف اللحنية.

بعد التطرق إلى مدرسـة زريـاب وتحليل خصائصها في الكشف عن الأصسوات ، وكذلك قواعده الخاصة في تعليم الألحان الغنائية لطلابه توصلت الباحثة إلى ما يلي : أولا : نتائج خاصـة بهذه المدرسـة في كشف الأصسوات يمكن الاستفادة منهـا في اختبار القدرات للطلاب المتخصصين : الطيان • يـري زريـاب أن أداء الطالب لكلمـة ( يـا حجـام ) تسـاعده في اختبـار قوة الصوت ومخارج الحروف .

• وأهتم زرياب بالتعرف علي المساحة الصوتية للتلميذ المختبر وذلك بأدائه كلمـة ( آه) علي جميع درجات السلم الموسيقي وبذلك التعرف علي مقدرته الغنائية ـ بلئ

• أهتم أيضا بالوقفة الصحيحة للمؤدي حتي يستطيع التنفس بشكل صحيح وعميق ، والعمل علي تقوية عضلات البطن والحجاب الحاجز حتي يخرج الصوت قويا ـ • اهتم زرياب بأن يكون الصوت مفتوحا وطبيعيا غير مكتوم أو مزموم • • كما اهتم بكثف عيوب النطق وزم الأسنان .

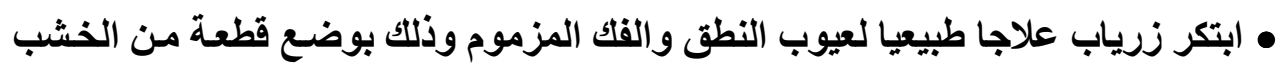
عرضها ثلاث أصابع في فم الطالب لمدة ثلاث ليالي حتي ينفرج فكاد. • كما اهتم بأخذ النفس وإخراجه . 


\section{ثانيا : نتائج خاصة بمدرسة زرياب في تعليم غناء الألحان :}

* يقرأ الطالب الكلمـات الشعرية ليتعرف علـي الميزان الشعري ، بالإضـافة إلى معرفة

$$
\text { معاني الكلمات وموقعها الأعرابي . }
$$

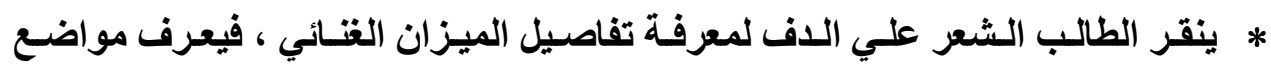

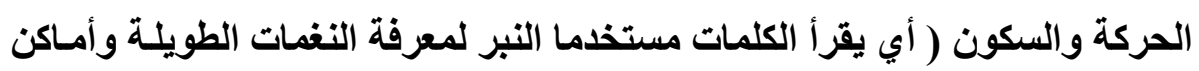

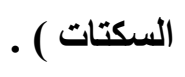

يمزج الثعر الموقع علي الدف حسب الإيقاع الموسيقي المطلوب بالألحان دون

$$
\text { أي زخارف أو طليات ويكرره حتي يتقنه . }
$$

تطلم مواضع الحليات بعد أن يكون الدارس قد أتقن اللدن وأصبح متمكنا في أدائه.

إمكانيـة الاستفادة مـن مدرسـة زريـاب في رفع مستوي الغتـاء العربـي القـليم للطالب

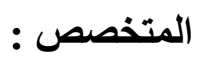

بعد أن توصلت الباحثة إلى معرفة أسلوب تعليم الغتاء العربي عند زرياب ، ومـا

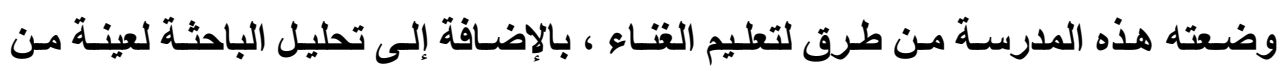

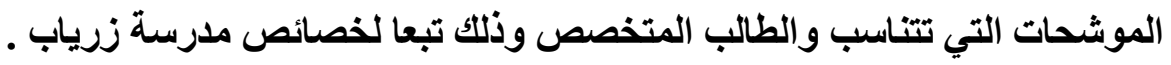

رأت الباحثة أن هذه الخصائص في الحقيقة هي التي يجب أن تفرض علي كل

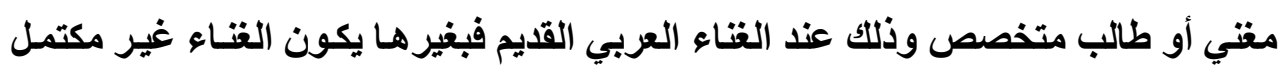




\section{أولا : هن هيث اختبار وتصنيف الأصوات :}

ا ـ يجب أن يقف الطالب عند الغناء معتدل القامة ، مفرود الصدر .

Y. أخذ نفس عميق قبل الغناء حتى يسهل أداء النغمات بتردداتها الصحيحة.

r. يقوم الطالب عند اختبـاره الأول بـأداء تمـرين صـولفيج علـي درجـات السلم المختلفـة

صعودا وهبوطا مستخدما لفظ (آه) وذلك لمعرفة (مساحته الصوتية).

ع. يمكن الاستفادة من طريقة زريـاب في معالجة عيوب النطق مثل ( زم الأسنان ) حتى يأخذ الفكان الوضع الصحيح للغناء .

•. استخدام كلمة (يا حجام ) لاختبار مخارج الحروف ، حيث يجب التأكد علي هذه النقطة في اختبار الطالب المتخصص حيث أنه فيما بعد سيكون مثنل يحتذي بـه فيجب أن تكون

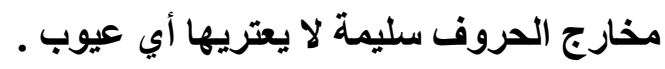

\section{ثانيا : من هيث تمليم فناء الألمان العربية :}

ا ـ يجب غناء الطلاب المتخصصين وهم مستخدمين المدونات الموسيقية

ץ. يجب أن يدرس الطالب النص الشعري من حيث الأوزان والضبط ثم يقر أه مستعينا بالاف لمعرفة النقر القوي والنقر الضعيف والسكتات ومنها معرفة الميزان الغتائي

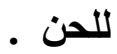

r. غناء اللحن بصورة مبسطة دون الزخارف اللحنية حتي يتم إتقان اللحن الأساسي . وتركيب الإيقاع علي اللحن أثناء الغناء باستخدام الدف أو اليا ـ ع. إدخـال الزخـارف اللحنيـة والحليـات الموسـيقية إلى اللحن ، بـذلك يكـون الطالب قد استطاع غناء اللحن بشكل سليم مصاحبا للإيقاع والزخارف اللحنية ، ودون عيوب

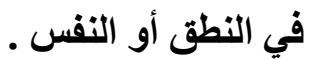

وهكذا فإن هذا النابغة الذي أرسي هذه القواعد والأسس قد سبق عصره بأجيال

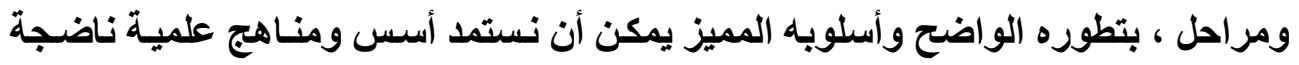


تجعل لهذا الفن منـاهج وخطوات يسير علي نهجها كل من يطلب الكمـال في أداء الغتـاء العربي .

\section{التوصيات :}

* ضرورة الاهتمام بمدارس الغناء العربي في العصور المختلفة مثل مدرسـة زريـاب ،

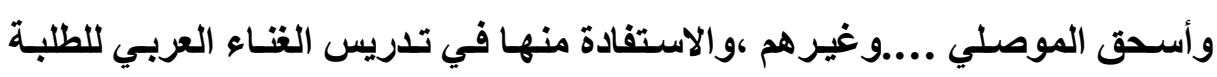
المتخصصين ولكل من يؤدي الغناء ـ

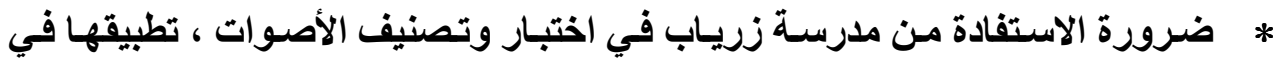

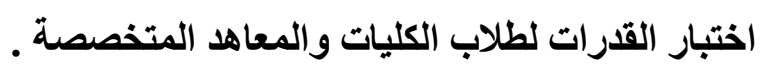
* رورة تطبيق مدرسة زرياب في تعليم الغناء العربي بالخطوات التدريجية المطلوبة. * إدراج قسم خاص بالغناء العربي بالكليات والمعاهد المتخصصة علي غرار قسم الغتاء

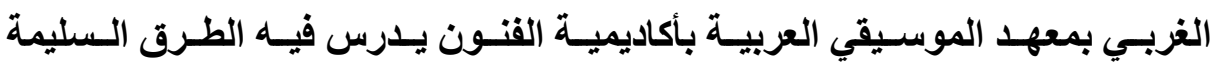
والمختلفة للغناء العربي .

\section{المراجهــع :}

أبو الفرج الأصفهاني : الأغانى، الجزء التاسـع ، دار التحرير للطبع والنشر ، القـاهرة ، $.19 \mathrm{~V}$.

أحمد سـعد : تقتيـات الغنـاء عند زريـاب ،رسـالة ماجستير غير منشفورة ، المعهد العـالي

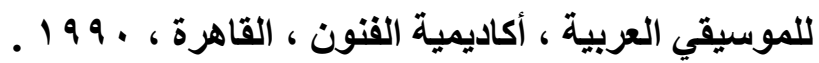
أحمد الجندي : من تاريخ الغتاء عند العرب ، طا ، وزارة الثقافة ، دمشث 9 ، 19 ـ راجي عنايت : علماء العرب للفتيان والفتايات (زرياب) ، زينب حسن : الفن المعاصر ، مجلة فصلية متخصصة ، أكاديمية القنون ، المجلد الأول ،

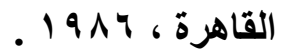

سمير شيخان : أشهر المغتين ، المطبعة الكاثوليكية ، بيروت . 
مجلة بحوث التربية النوعية - العدد الرابع-يوليو ع... F

علي إبراهيم حسن : التاريخ الإسلامى العام ، مكتبة النهضة ، القاهرة ، بلون تاريخ . عواطف الثرقاوي : طرق الغناء العربى وإمكانية تطويعها لأصوات اللغة العربية ، رسـالة دكتوراه منشورة ، الكونسيرفاتوار ، القاهرة ، 1919

عبد الحميد العايدي : المجمل فى تـاريخ الأندلس ، المكتبـة التاريخيـة ، دار العلم القـاهرة $.197 \varepsilon$

عبد الحميا مشعل : موسيقى الغتاء العربى طرابلس ليبيا ، دار مكتبة الفكر ، طرابلس ليبيا . 19V\%。

عبد الحميد مشعل : مراحل تطور الموسيقى العربية و الموشحات العربية ،دار مكتبة الفكر

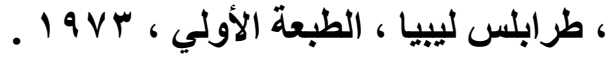

فاطمة أحمد إبراهيم غريب : أساليب تدوين الإيقاعات العربية في العصر العباسى وإمكانية الاستفادة منها في تدريس الإيقاعـات والضروب العربيـة ،رسـالة ماجستير

غير منشورة ، كلية التربية النوعية ،ج عين شمس ، القاهرة ، 999 ا 19 ـ

كمال النجمى : تراث الغتـاء العربــ بين الموصلِ وزريـاب وأم كثثوم وعبد الوهـاب ، دار

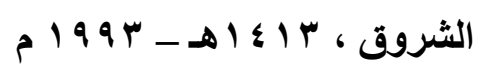

محمود أحمد الحفني : زرياب أبو الحسن على بن نافع ، الدار المصرية للتأليف ، 19 ا 19 مجدي العقيلي : السماع عند العرب ، الجزء الثاني ، الطبعة الأولي ، ، I9 I . محمد سالم : الرائد في تجويد القرآن ، مكتبة الأنجلو المصرية ، القاهرة . محمد كامل الخلعي : الموسيقى الثرقي ، مطبعة التقدم شارع محمد علي ، القاهرة ، مصر $.199 \%$ ،

محمد محمود سامي حافظ : تاريخ الموسيقى والغتاء العربي ، مكتبة الأنجلو المصرية ،

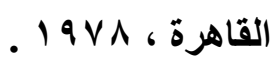


نبيل عبد الهادي شـورة : قراءات في تـاريخ الموسيقي العربيـة ، دار العلاء للطباعـة،

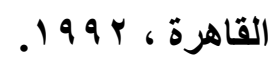

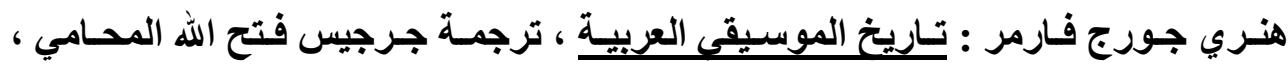

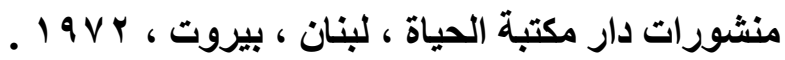

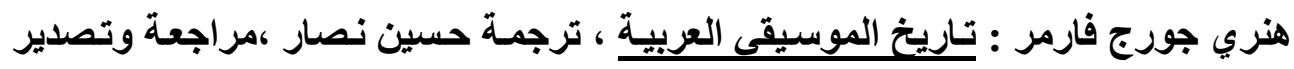

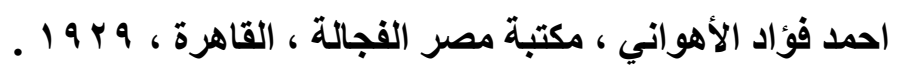




\section{هذمب البمث}

\section{توظظيف خمائص هدرسة زرياب في الغناء العربي}

\section{لطلاب الكليات المتفصصة}

د. / فاطمة أحمد إبراهيم غريب

استهل البحث بمقدمة توذضح أهمية الصوت البشري ، وضرورة تدريبه علي أسس فنية ،ومنهجية صحيحة ، ورأت الباحثة أن هناك عدة مدارس للغناء العربي القديم ، يمكن

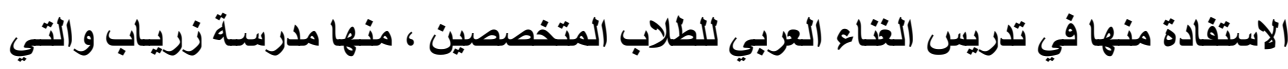
أنشأها بقرطبة، في العصر الأندلسي ، أوائل القرن التاسع الميلادي ـ

ويرجع الفضل لزرياب في وضع أسلوب مبتكر لاختبار وتعليم الأصوات الغنائيـة حيث

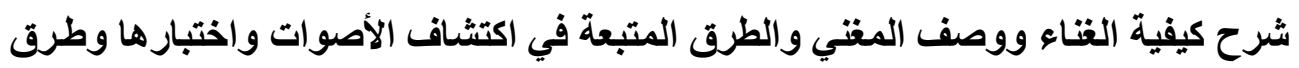

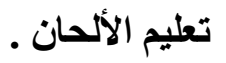

وقد قسم طريقته في تعليم الألحان إلى ثلاث مراحل وهي :

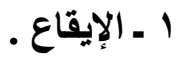

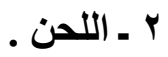
ب ـ الزخارف اللحنية . وينقسم البمث إلى جرأين : الجزء الأول : الإطار النظري ويتناول المقدمة ، مشكلة البحث ، أهمية البحث ، فروض البحث ، إجراعات البحث ، منهج

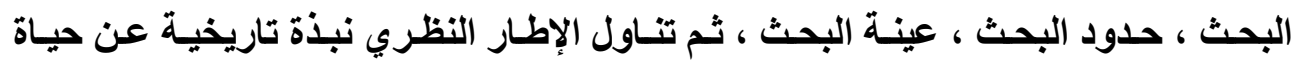
زرياب . 


\section{الجزء الثانى : الإطار التحيليى ويتناول}

شرح وتحليل مدرسـة زريـاب في اختبار وتصنيف الأصوات وإمكانيـة الاستفادة

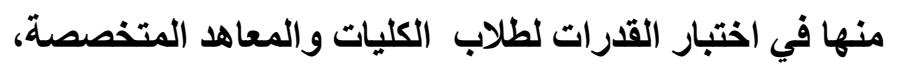

بالإضافة إلى شرح وتحليل طريقته في تعليم الألحان الغنائية وتطبيق مراحلها التدريجية علي الموشحات عينة البحث .

ثم اختتم البحث بالنتائج ،والتوصيات المقترحة ومن أهمها :

• ضرورة الاهتمـام بمدارس الغتـاء العربـي المختلفـة علـي مر العصور ومنهـا مدرسـة

$$
\text { زرياب . }
$$

• إدراج قسم يهتم بتدريس الأسس العلمية السليمة والأسـاليب المختلفة للغتـاء العربي

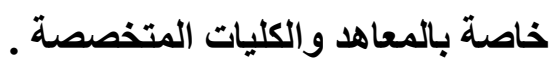

• الاهتمام بتدريس علم التجويد ، ومخارج الألفاظ لطلاب المعاهد والكليات المتخصصة. وأخيرا مراجع البحث ثم الملخص . 
$-1+9-$ 
$-1 \leqslant-$ 
$-1 \leqslant 1-$ 